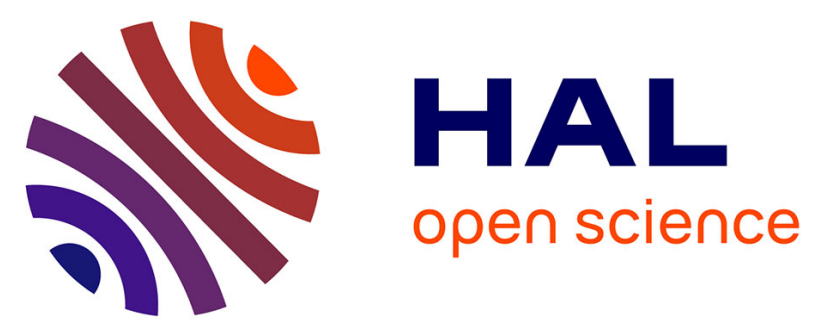

\title{
Extraordinary majoid crabs: the genus Esopus A. Milne-Edwards, 1875 in the new subfamily Esopinae subfam. nov., and erection of Paulitinae subfam. nov. (Crustacea, Decapoda, Brachyura, Majoidea, Inachoididae Dana, 1851)
}

Danièle Guinot, Barry W M van Bakel

\section{To cite this version:}

Danièle Guinot, Barry W M van Bakel. Extraordinary majoid crabs: the genus Esopus A. MilneEdwards, 1875 in the new subfamily Esopinae subfam. nov., and erection of Paulitinae subfam. nov. (Crustacea, Decapoda, Brachyura, Majoidea, Inachoididae Dana, 1851). Zootaxa, 2020, 4766 (1), pp.101-127. 10.11646/zootaxa.4766.1.5 . hal-02888733

\section{HAL Id: hal-02888733 \\ https://hal.sorbonne-universite.fr/hal-02888733}

Submitted on 3 Jul 2020

HAL is a multi-disciplinary open access archive for the deposit and dissemination of scientific research documents, whether they are published or not. The documents may come from teaching and research institutions in France or abroad, or from public or private research centers.
L'archive ouverte pluridisciplinaire HAL, est destinée au dépôt et à la diffusion de documents scientifiques de niveau recherche, publiés ou non, émanant des établissements d'enseignement et de recherche français ou étrangers, des laboratoires publics ou privés. 


\title{
Extraordinary majoid crabs: the genus Esopus A. Milne-Edwards, 1875 in the new subfamily Esopinae subfam. nov., and erection of Paulitinae subfam. nov. (Crustacea, Decapoda, Brachyura, Majoidea, Inachoididae Dana, 1851) \\ DANIÈLE GUINOT ${ }^{1} \&$ BARRY VAN BAKEL ${ }^{2}$
}

${ }^{1}$ YSYEB (CNRS, MNHN, EPHE, Sorbonne Université), Institut Systématique Évolution Biodiversité, Muséum national d'Histoire naturelle, case postale 53, 57 rue Cuvier, F-75231 Paris cedex 05 (France). Email: guinot@mnhn.fr

${ }^{2}$ Oertijdmuseum, Bosscheweg 80, 5283 WB Boxtel, the Netherlands. Email: barryvanbakel@gmail.com

Corresponding author. DANIÈLE GUINOT, guinot@mnhn.fr

\begin{abstract}
A rare small species, Esopus crassus A. Milne-Edwards, 1875, recently collected by KARUBENTHOS Expedition 2015 in Guadeloupe, is re-examined. The genus Esopus A. MilneEdwards, 1875, currently included in the Epialtidae MacLeay, 1838, must be assigned to the Inachoididae Dana, 1851, a rather basal family within the Majoidea Samouelle, 1819, but deviates from the morphotype that is being traditionally associated to this group. It deserves its own subfamily, Esopinae subfam. nov., besides other inachoidid subfamilies, for which a description is here provided (Collodinae Stimpson, 1871; Dasygyiinae Holmes, 1900; Inachoidinae Dana, 1851; Salaciinae Dana, 1851; Stenorhynchinae Dana, 1851). Another inachoidid subfamily is erected here, Paulitinae subfam. nov., for the genus Paulita Guinot, 2012, monotypic with P. tuberculata (Lemos de Castro, 1949, as Dasygyius tuberculatus). A reliable fossil member is recorded from the lower Miocene onwards.
\end{abstract}

Key words: Majoidea, Inachoididae, Collodinae, Dasygyiinae, Inachoidinae, Salaciinae, Stenorhynchinae, Paradasygyius, Paulita, Esopus, Esopinae subfam. nov., Paulitinae subfam. nov., pleurites, new subfamilies, fossil

\section{Introduction}

Within the monophyletic Majoidea Samouelle, 1819, a superfamily that comprises almost 1000 species in more than 200 genera ( $\mathrm{Ng}$ et al. 2008, updated) and whose relationships between the 
constituent families are still hotly debated, some genera deviate from the morphotype that is being traditionally associated to this group. This is the case of the monotypic genus Esopus, characterised by a narrow carapace, with parallel lateral margins, by a strongly sculpted dorsal surface, and by a rostrum with a rather unique arrangement. It was established by A. Milne-Edwards in 1875 for a small species collected at $183 \mathrm{~m}$ by the "Hassler" off Barbados, Sandy Bay (Lesser Antilles of the West Indies), E. crassus A. Milne-Edwards, 1875 (A. Milne-Edwards 1875; 1880; A. MilneEdwards \& Bouvier 1923), and well redescribed after the holotype by Rathbun (1925). The second report of the species corresponds to the capture of several males and females from the north of Cuba between 329-403 $\mathrm{m}$ (Chace 1940). The third report is the recent discovery by KARUBENTHOS Expedition 2015 of nine samples from Guadeloupe (Marie-Galante, La Désirade), in the French West Indies, Lesser Antilles, at similar depths (Carmona-Suárez \& Poupin 2016; Poupin \& Corbari 2016; Poupin 2018).

The genus Esopus, first considered a link between the Pericerinae Dana, 1851 and the Parthenopinae MacLeay, 1838 (A. Milne-Edwards 1875), was assigned to the Microrhynchinae Miers, 1879 (Miers 1879), to the Acanthonychinae Alcock, 1895 (Rathbun 1925), to the Majidae Samouelle, 1819 (Chace 1940), and to the Epialtidae MacLeay, 1838 by all subsequent authors, including Ng et al. (2008: 100). In a paper focusing on the earliest Brachyura in the fossil record, Guinot (2019), who examined the specimens collected by KARUBENTHOS Expedition and presently deposited in the MNHN, referred Esopus to the Inachoididae Dana, 1851.

The illustrations of Esopus crassus by A. Milne-Edwards (1875: pl. 17, fig. 1-lc), all reproduced by Rathbun (1925: pl. 222, figs. 10-12), are excellent, as well as the descriptions. But none of these authors noticed the exceptional arrangement of the carapace, the edges of which fit into a semi-circle groove hollowed in the lateral part of the pleural walls, the 'setting gutter': the dorsal cover of the crab includes not only the carapace sensu stricto but also the lateral regions of the pleurites 5-8 and, in addition, the first pleonal somite (Figs. 1, 2A). These unique features are exclusive of the Inachoididae, a family resurrected by Drach \& Guinot (1982, 1983), and including the genus Leurocyclus Rathbun, 1897 (Guinot 1984). The only reference to a particular conformation was the brief mentions of "epimeral plates" in Paradasygyius tuberculatus (Lemos de Castro, 1949) by Rathbun (1925: 138) [now Paulita tuberculata (Lemos de Castro, 1949)], and in Dasygyius depressus (Bell, 1835) [now Paradasygyius depressus (Bell, 1835)] by Garth (1958: 80, 82) [“epimeral plates" correspond to "pleural plates", the term "epimeral" having been modified to “pleural” by Secretan (1977)].

Most of the inachoidid genera were previously assigned to the Inachinae MacLeay, 1838 (e.g., Rathbun 1925; Garth 1958; Williams 1965, 1984); a key to the western Atlantic 
inachines (including inachoidids) was provided by Williams (1984: 292). The family Inachoididae, examined in detail by Guinot \& Richer de Forges (1997) and Guinot (2012: figs 1, 2A, B), and revised by Santana (2008), differs from the Inachidae MacLeay, 1838 by the skeletal configuration. In Inachidae only pleurites 6-8 are exposed, and also significantly less (in particular 6,8) than in Inachoididae, and only showing as minute pointed sclerites; as a result, the inachid carapace is not inserted into a continuous setting gutter (Guinot 2012; Guinot et al. 2013: fig. 49A). The taxonomy of the Inachidae was recently significantly modified, notably with the exclusion of Macrocheira De Haan, 1839 and Macrocheiridae Dana, 1851 (Guinot \& Bouchard 1998: 658; Guinot et al. 2013: 231; 2019: 3012) according to the results of Clark \& Webber (1991) and Marques \& Pohle (1998), and with the removal of several genera for a placement within the Oregoniidae (Marco-Herrero et al. 2013; Ng et al. 2017; Ahyong et al. 2019).

A little digression is relevant here. The genus Capartiella Manning \& Holthuis, 1981, monotypic with $C$. longipes (Capart, 1951), shows the typical inachid groundplan. The original drawing of $C$. longipes (clearly showing the exposure of several pleural sclerites) by Capart (1951: fig. 19, as Achaeus? longipes), reproduced by Monod (1956: fig. 746, as Physachaeus (?) longipes) and by Manning \& Holthuis (1981: fig. 69), is not an accurate depiction of the species because it does not reflect the more triangular shape of the carapace, see Guinot et al. (2013: fig. 49A). As in other Inachidae, small lateral portions of pleurites 58 are exposed laterally, remaining detached from the carapace as sclerites located below the carapace, instead of being "integrated" to the lateral carapace edge, so the carapace does not rest on a setting gutter, unlike the typical inachoidid condition; likewise, the first pleonal somite is not part of the carapace, which does not correspond to the inachoidid condition (Figs 1, 2A). Guinot \& Richer de Forges (1997: 489, fig. 15D, E, G) and Guinot et al. (2013: fig. 49C, D), hypothesised that the flap on each part of the pleotelson of $C$. longipes could correspond to a vestigial uropod, perhaps homologous to the intercalated platelets of the basal hymenosomatoid Odiomarinae Guinot, 2011 (Guinot 2011a), the retention of a true uropod in Odiomarinae and of a moveable flap in Capartiella being probably inherited from a close common ancestor rather than indicative of convergence.

We will justify our decision to assign Esopus to the Inachoididae in detail here. However, with its narrow body, its thick, oval lobulated and grooved carapace, its rostrum that lowers ventrally in the form of a narrow, tuberculiform one-piece part, its antenna with an enormous basal article, and its short eyestalks located in postocular cups, Esopus is rather unique within this family. Although the present paper does not purport to be a revision of the Inachoididae, we believe that 
Esopus deserves its own subfamily, Esopinae subfam. nov., alongside the already existing subfamilial taxa, for the most part actually not currently implemented: Collodinae Stimpson, 1871, Dasygyiinae Holmes, 1900, Inachoidinae Dana, 1851, Salaciinae Dana, 1851, for which updated diagnoses are provided; and one recently recognised, the Stenorhynchinae Dana, 1851 (Guinot 2012).

In addition, we here erect another subfamily, the Paulitinae subfam. nov., for the genus Paulita Guinot, 2012, characterised by several parallel, deep grooves that deeply cut the dorsal surface of the carapace of P. tuberculata (Lemos de Castro, 1949: figs. 1, 2A, B, as Dasygyius tuberculatus), a unique inachoidid and even eubrachyuran disposition (Guinot 2012: figs. 1, 2A, B).

Fossils assigned to Inachoididae are rather scarce, and we will briefly review the few species that can be assigned to this family.

\section{Material and methods}

Measurements refer to carapace length $\times$ carapace width, including spines, teeth, and the exposed pleurites 5-8 as well as the first pleonal somite that is dorsally exposed. The following abbreviations are used: G1, first male pleopod, or first gonopod; $\operatorname{mxp} 2, \operatorname{mxp} 3$, second and third maxillipeds; P1-P5, first to fifth pereopods (P1 as chelipeds). The thoracic somites are numbered from 1 to 8 . The thoracic sternal sutures are referred to by the number of the two thoracic sternites that they involve and thus are numbered from $1 / 2$ to $7 / 8$. The pleonal somites are numbered from 1 to 6; the telson can be fused to a various number of somites, so the pleotelson can include somite 6 plus telson or somites 5 and 6 plus telson. The material examined is deposited in the Muséum national d'Histoire naturelle, Paris (MNHN).

\section{Institutional abbreviations.}

MCZ, Museum of Comparative Zoology, Cambridge, MA, USA;

MNHN, Muséum national d'Histoire naturelle, Paris, France

\section{SYSTEMATICS}

Section Eubrachyura Saint Laurent, 1980

Subsection Heterotremata Guinot, 1977

Superfamily Majoidea Samouelle, 1819

Family Inachoididae Dana, 1851 
Inachoidinae Dana, 1851: 432.

Inachoidinae Dana 1853: 1421.—Neumann 1878: 13.—Manning \& Holthuis 1981: 252.-Melo, 1996: 191.-Poore 2004: 364.

Inachoididae Drach \& Guinot 1983: 37-42.-Guinot 1984: 377-395.-Guinot \& Richer de Forges 1997: 483-492.-Hendrickx 1999: 50.—Števčić 2005: 99.—Coelho 2006: 683, 684.-Wicksten 2008: 296.-Santana 2008: 1-245.—Santana \& Tavares 2008: 317.—Ng et al. 2008: 115.—Guinot 2012: 22 -40._Santana \& Tavares 2017: 1145._Guinot et al. 2019: 302, 313, 314._Guinot 2019: 783.

Subfamily Esopinae Guinot \& Van Bakel, subfam. nov.

Type genus. Esopus A. Milne-Edwards, 1875 (type species by monotypy: Esopus crassus A. Milne-Edwards, 1875).

Description. Body thick. Carapace much longer than wide, narrow, gibbous, resting on setting gutter receiving carapace edge. Whole body with very thick cuticle. Dorsal surface sculpted, with inflated regions: frontal (tripartite), gastric (subdivided into several swollen portions), cardiac (prominent), intestinal (flat), delineated by several deep grooves. Exposure of latero-external portions of pleurites 5-8, calcified and ornamented like dorsal carapace surface, forming wide collar all around posterolateral margins of carapace; first (male and female) pleonal somite dorsal and similarly included in collar; pleonal somites 2-3 and portion of 4 dorsally visible. Portion in front of eyes delimited by deep depression and marked constriction; interorbital space divided into three nearly equal elevated lobes by two longitudinal depressions. Front broader than long. Rostrum wide, blunt, strongly folded downwards in the form of protruding, narrow, beak-shaped piece, positioned between antennules (as proepistome) and joins long anterior process of epistome. Antennular fossae (arthrodial cavities of antennules) very narrow, closed; antennules folded almost longitudinally. Antenna: articles 1 (urinary) et $2+3$ (basal) adjacent; basal article coalescent with rostrum and epistome, very large, without keel, prominent, extending well beyond eyes, each expanding medially on epistome and thus close to the corresponding article of the other side; its distal and disto-lateral portions visible dorsally; other antennal articles proportionally very small in size; articles 4, 5 free; flagellum very short. Preorbital tooth absent. Ocular peduncle stout, protected in orbit. Postorbital tooth thick, cup-shaped to receive eye, fused with rounded subhepatic region. Epistome rather small. Buccal cavity wide. Milne-Edwards 
openings separated from chelipeds, entirely filled by developed mxp3 coxa. Mxp3 flat, completely covering buccal frame, operculiform; merus slightly dilated outward and forward, slightly notched on inner side for insertion of palpus; crista dentata with small teeth and row of setae. Branchiostegite extremely reduced. Male chelipeds very long, usually more than twice as long as the carapace; large gap between the fingers, near base. Female chelipeds shorter, less than length of carapace; fingers not gaping. Ambulatory legs very slender, rather long, unarmed; merus without spine on dorsoproximal margin; dactyli very thin, long, not subchelate, aplying along propodi. Female sterno-pleonal cavity deeply hollowed. Female pleon wide, swollen, forming large disc limited by high sternal ridge, and formed of four somites, the somites 5, 6 being coalescent into pleotelson. Male pleon composed of somites 1-5 free plus pleotelson (somite 6 plus telson). Female pleon composed of somites $1-4$ free plus pleotelson (somites 5, 6 plus telson). Male thoracic sternum markedly wide, with strong ridges and depressions, granular on exposed surface, smooth inside sterno-pleonal cavity; anterior shield formed by fused sternites 1-3 without demarcation in both sexes, as triangular, inflated, produced plate inserted between mxp3; a depression at level of suture 3/4; lateral extension of sternite 3 very short, hardly visible; sutures 4/5-7/8 interrupted; deep small depression at base of sternite 8 , instead of median line. Sternum/pterygostome junction complete due to curved anterior extensions of sternite 4. Sternal extensions joining exposed pleurites (sternum/pleurites connections): wide between P1/P2, narrower between P2/P3, P3/P4, P4/P5. Female thoracic sternal sutures obliquely directed forward. Vulvae produced, on anteriorly displaced sternite 6. Partial condylar protection of penis, penis emerging from anterior border of P5 coxo-sternal condyle. G1 with broadened half proximal portion, and apical lobe bearing aperture; G2 very short. Pleonal-locking system consisting of buttons on sternite 5, sockets on pleotelson.

\section{Remarks.}

In Esopus crassus the rostrum extends ventrally in a thick, beak-shaped piece, gradually tapering off, that is positioned between the antennules; it does not develop any spine (Figs. $2 \mathrm{~B}, \mathrm{C}, 3 \mathrm{~A})$; in oblique view, after removing the antennule, only a thick septum is visible. In Esopus it is the ventral part of the rostrum itself that just comes between the antennules and takes the place, at least without dissection of the region underneath, of the 'proepistome', the 'antennular septum' or 'interantennular septum' of authors. The proepistome is a structure defined as the "median, ventrally directed, cuticular outgrowth that separates the two cavities into which each antennule may be retracted" (Ingle 1983: 6) or "the plate separating 
antennular cavities" (McLaughlin 1981: 167). In fact, the proepistome represents the sternite of the antennular somite (the first cephalic somite) and, if so, may connect to the epistome (sternite of the antennal somite) and thus attaches the carapace to the sternal surface. The term 'outgrowth' actually covers a set of modalities since in Brachyura this rostral outgrowth occurs in a wide variety of forms, and especially in Majoidea, in which the rostrum is often well developed and highly diverse. Among the Brachyura, the similarity of position (topographic and position in relation to other parts) of the rostral outgrowth is obvious, but a real homology between all the conditions is to be studied. In Esopus the last portion of the curved rostrum reaches the spiniform anterior process of the epistome. According to Cano (1893: 38, figs. 48a-c, 81) in spider crabs the primitive rostrum folds down to form a septum between the two antennules to join to a median process of the epistome; the interantennular septum would be the true rostrum of the zoea, the so-called rostrum of the adult being a secondary outgrowth of the front (see Balss 1929: 2; Garth 1958: 7-8). The different character states of the proepistome structure (often ignored by carcinologists) are very important for the phylogeny of Brachyura.

Another point deserves to be clarified. By using the term 'fused' loosely, it can mean that there is a real fusion process, thus without visible sutures (as in the case of the basal antennal article consisting of 2 and 3 fused articles in most Brachyura; or in the case of the thoracic sternum, where sternites are more or less fused); but it can also simply mean that two structures are in very tight contact but remain separate.

Genus Esopus A. Milne-Edwards, 1875

Esopus A. Milne-Edwards 1875: 89.--Miers 1879: 651.-A. Milne-Edwards \& Bouvier 1923: 389._- Rathbun 1925: 191.—Ng et al. 2008: 100._Guinot 2019: 783.

\section{Esopus crassus A. Milne-Edwards, 1875}

Figs. 1-4

Esopus crassus A. Milne-Edwards, 1875: 91, pl. 17, fig. 1-lc.-A. Milne-Edwards 1880: 2.-A. Milne-Edwards \& Bouvier 1923: 389.-Rathbun 1925: 192, pl. 222, figs. 10-12.—Chace 1940: 61, fig. 21A, B.-Ng et al. 2008: 100._Carmona-Suárez \& Poupin 2016: 384._Poupin \& Corbari 2016: fig. 15k.-Poupin 2018: 184, fig. 198._Guinot 2019: 783, 787, figs. 19A, B, 20.

Type data. Holotype: Female $9.0 \times 15.0 \mathrm{~mm}(\mathrm{MCZ})$ [Curiously, although "the species is known by the unique type", Rathbun (1925: 192) provided for the female holotype a 
significantly higher size, $13.0 \times 8.4 \mathrm{~mm}$, than that provided by A. Milne-Edwards (1875: 91$)$, i.e. the above-mentioned measurements.

Type locality. Lesser Antilles of the West Indies, off the Barbados, Sandy Bay, 183 m, "Hassler" Expedition led by L. Agassiz in 1871-1872, from Cambridge to San Francisco, California, around coasts of South America.

\section{Material examined}

One ovigerous female $11.0 \times 6.7$ mm, Guadeloupe, W Marie-Galante, KARUBENTHOS 2, st. DW4586, $15^{\circ} 59.62^{\prime} \mathrm{N}, 61^{\circ} 22.51^{\prime} \mathrm{W}, 251-204 \mathrm{~m}, 21$ June 2015, with some large eggs remaining from a recent egg-laying, MNHN-IU-2013-19002 (Figs. 2, 3); one male $9.1 \times 5.5 \mathrm{~mm}$, Guadeloupe, W Marie-Galante, KARUBENTHOS 2, stn DW4592, 155' $\mathrm{N}, 61^{\circ} 22^{\prime} \mathrm{W}, 201-214$ m, 22 June 2015, MNHN-IU-2016-2530; one male $9.1 \times 5.4 \mathrm{~mm}$, one female $11.3 \times 6.9 \mathrm{~mm}$, Guadeloupe, $\mathrm{W}$ Marie-Galante, KARUBENTHOS 2, stn DW4597, 155' $\mathrm{N}, 61^{\circ} 23^{\prime} \mathrm{W}, 208-210$ m, 22 June 2015, MNHN-IU-2016-2350; 2 ovigerous females $10.5 \times 6.2 \mathrm{~mm}, 10.7 \times 6,4 \mathrm{~mm}$, Guadeloupe, S MarieGalante, KARUBENTHOS 2, st. DW4637, 16 ${ }^{\circ} 52^{\prime} \mathrm{N}, 61^{\circ} 20^{\prime} \mathrm{W}, 217-225$ m, 28 June 2015, MNHNIU-2016-2562; 3 ovigerous females $10.7 \times 6.6 \mathrm{~mm}, 10.7 \times 6.4 \mathrm{~mm}, 10.4 \times 6.3 \mathrm{~mm}$, one female 10.5 $\times 6.3 \mathrm{~mm}$, Guadeloupe, S Marie-Galante, KARUBENTHOS 2, st. DW4638, 1550.29'N, 61⒚47'W, 312-305 m, 28 June 2015, MNHN-IU-2013-19150; one male $10.8 \times 6.9 \mathrm{~mm}$ (photographed Fig. 4), MNHN-IU-2019-2552; 2 males $10.5 \times 6.4$ mm, $10.4 \times 6.6$ mm, 6 females (3 ovigerous), $12.2 \times 7.9 \mathrm{~mm}, 12.1 \times 7.4 \mathrm{~mm}, 12.0 \times 7,4 \mathrm{~mm}, 11.8 \times 7.0 \mathrm{~mm}, 11.5 \times 6,9 \mathrm{~mm}, 10.9 \times$ $6.6 \mathrm{~mm}$, Guadeloupe, S Marie-Galante, KARUBENTHOS 2, st. CP4624, $15^{\circ} 57^{\prime} \mathrm{N}, 61^{\circ} 32^{\prime} \mathrm{W}, 242-$ 243 m, 26 June 2015, MNHN-IU-2016-8345; one female $10.5 \times 6.3$ mm, MNHN-IU-2016-2571; one female $11.1 \times 6.6 \mathrm{~mm}$, Guadeloupe, S Marie-Galante, KARUBENTHOS 2, stn DW4645, $15^{\circ} 52^{\prime} \mathrm{N}, 61^{\circ} 20^{\prime} \mathrm{W}, 208-210 \mathrm{~m}, 29$ June 2015, MNHN-IU-2016-2631; one female $8.9 \times 5.4 \mathrm{~mm}$, Guadeloupe, E Desirade, KARUBENTHOS 2, st. DW4560, 16² $25^{\prime} \mathrm{N}, 60^{\circ} 52$ 'W, 185-250 m, 16 June 2015, MNHN-IU-2016-2061; one ovigerous female $11.1 \times 6.8 \mathrm{~mm}$, Guadeloupe, E Desirade, KARUBENTHOS 2, st. CP4569, 16²17.25'N, 61ํํ' 'W, 250-359 m, 17 June 2015, MNHN-IU2013-18951 (Fig. 1, crab photographed on board).

\section{Redescription}

Carapace narrow, much longer than wide, gibbous (Fig. 1). Cuticle very thick, hard. Lateral margins rounded, without spines. Dorsal surface as blistered, sculpted, with conspicuously inflated regions delineated by several deep, marked grooves, entirely covered by pronounced rounded granules; no spines; only some setae; four main distinct areas: frontal (tripartite, posteriorly limited by deep depression), gastric (elevated, divided in prominent regions: protogastric mesogastric, metagastric, 
urogastric), cardiac (swollen), intestinal (flat). Cervical groove widely U-shaped, medially interruped. Cardiac region prominent; intestinal region large, flat; branchial region weakly subdivided. Dorsal surface and most part of ventral surface of body covered by rounded, almost confluent granules. Exposure of latero-external portions of pleurites 5-8 on same level as carapace, calcified and ornamented like dorsal carapace surface, forming wide collar all around posterolateral margins of pleural walls, and including wide and dorsal first (male and female) pleonal somite, similarly 'integrated' to carapace (Fig. 2A). Portion in front of eyes delimited by deep transversal depression; interorbital space divided into three nearly equal lobes by two longitudinal depressions. Front broader than long, formed by large, rounded, tuberculiform prominence, with two tiny spines (hardly noticeable) on each side; folded ventrally. Rostrum wide, blunt in dorsal view, strongly deflexed, protruded downward as narrow, granulate beak-shaped plate (?proepistome) joining long and slender anterior process of epistome (Figs. 1, 2B, 3A, 4A). Antennular fossae very narrow; antennules folded almost longitudinally in closed fossae. Antenna: article 1 (urinary) with rounded urinary orifice; basal article (articles 2+3) adjacent to article 1 coalescent with rostrum and epistome, very large, markedly prominent, extending well beyond eyes, without keel, covered with rounded granules; distal and disto-lateral portions visible dorsally; each basal article expanding medially on epistome by two large, rounded tubercles and thus close to the corresponding article of other side; following antennal articles proportionally very small in size; articles 4, 5 free; flagellum very short (Figs. 3A, 4A). Preorbital tooth absent. Ocular peduncle short, stout, folding into a fossa, i.e. incomplete orbit, formed by frontal edge and subhepatic region. Postorbital tooth thick, fused to rounded subhepatic region and cup-shaped to receive eye. Branchiostegite extremely reduced. Constriction of carapace marked ventrally, at level of epistome. Epistome rather small, recessed, forming posteriorly narrow raised wall, with straight margin. Buccal cavity wide. Milne-Edwards openings separated from chelipeds, large, entirely filled by developed mxp3 coxa (Figs. 3A, 4A, B). Mxp3 flat, completely covering buccal frame; merus slightly dilated outward and forward, slightly notched on inner side for insertion of palpus; crista dentata with small teeth and row of setae. Male chelipeds very long, narrow, usually more than twice as long as carapace; large gap between fingers, near base (Chace 1940: fig. 21B). Female chelipeds shorter, less than length of carapace; fingers not gaping (Fig. 1); in females, fingers proportionally much shorter than palm compared to male fingers and palm. Ambulatory legs very slender, rather long, without any spines, with short setae; merus without spine(s) on dorsoproximal margin; dactyli very thin, long, not subchelate, applying along propodi; P2-P5 dactyli with longer setae. Female sterno-pleonal cavity deeply hollowed. Female pleon formed of four somites, somites 5-6 coalescent with pleotelson, swollen, forming large disc limited by high sternal ridge, and without spine or tooth (Figs. 1, 2A, 3B); 
pleonal somites 2, 3 and portion of 4 visible dorsally. Male pleons composed of five free somites plus pleotelson (somite 6 plus telson), first somites dorsally exposed (Fig. 4A, B). Male thoracic sternum markedly wide, with strong granular ridges and depressions, continuing in smooth condition inside sterno-pleonal cavity; anterior shield inserted between $\operatorname{mxp} 3$ as broadly triangular, inflated plate, separated by depression from following sternites: sternites 1-3 fused without visible demarcation in males (Fig. 4A, B) (Chace 1940: fig. 21A), as small, narrow, semingly undivided piece in front of sternal wall in ovigerous females (Fig. 3B); suture 3/4 in depression; sternite 4 not inflated; sutures 4/5-7/8 interrupted, located in depressions, continuing on sides of sterno-pleonal cavity. Deep, small depression at base of sternite 8, instead of median line. Sternum/pterygostome junction complete thanks to curved anterior extensions of sternite 4. Wide sternal extensions joining exposed pleurites (sternum/pleurites connections) between P1/P2, P2/P3, P3/P4, and P4/P5 (Fig. 4B). Female thoracic sternal sutures obliquely directed forward. Vulvae anteriorly displaced, with protruded openings on forward projected sternite 6 , anteriorly to suture 4/5 (Fig. 3C). G1 slightly curved, with broadened half proximal portion, ending in distal lobe with large aperture (Fig. 4C); G2 very small. Ovigerous females with few large eggs.

Remarks. Esopus, which is monotypic, shares the synapomorphies that support the family Inachoididae, i.e. the typical inachoidid organisation, with the exposure of pleurites and pleon significantly increasing the surface area of the "carapace" and the edge of the true carapace in a setting gutter (Figs. 1, 2A). But Esopus differs from other inachoidids by a unique combination of characters: body particularly thicker; dorsal surface strongly lobulated and grooved (Fig. 1); disposition of rostrum and proepistome; antennae (Figs. 2C, 3A, 4A) (see also the excellent figure by A. Milne-Edwards 1875: pl. 17 fig. 1c; reproduced by Rathbun 1925: pl. 22, figs. 10-12); short eyestalk included in an incomplete orbit, posteriorly bordered by thick, curved, cup-shaped postorbital tooth fused to subhepatic region (Fig. 2B, C); sternum/pterygostome junction complete, due to curved extension of sternite 4; MilneEdwards openings separated from chelipeds, large, entirely filled by Mxp3 coxa; thoracic sternum with thick granular ridges (Fig. 4A, B) between the sutures; G1 with distal lobe (Fig. 4C). These features are sufficient to introduce for the genus a new subfamily, Esopinae subfam. nov., within the Inachoididae whose characters we will briefly review below.

\section{THE FAMILY INACHOIDIDAE}


A series of unambiguous synapomorphies support the family Inachoididae. The main inachoidid features are: exposure of the latero-external portions of pleurites 5-8 that, usually calcified and ornamented like dorsal surface, extend beyond each side of carapace. These external sclerites form a kind of collar all around the posterolateral margins of the carapace (irregular, however in Stenorhynchus Lamarck, 1818); this collar comprising, in addition, the wide and dorsal first (male or female) pleonal somite also incorporated into the carapace (thus appearing as part of the carapace) (Drach \& Guinot 1982: pl. 1, figs. 1-6; 1983: pl. 1, figs. 1-8); carapace setting in a gutter (except for Stenorhynchus); absence of a true branchiostegite posterior to P2, i.e. carapace without lateral-ventral folding and not covering the insertion area of the pereiopods; thoracic sternum/pterygostome junction at sternite 4 level varying from absent (Leurocyclus, Paradasygyius) to complete (Esopus, Paulita), with intermediate states (Collodes sensu lato, Inachoides); sternal extensions between pereiopods, from P1 to P4, usually present; thoracic sternum broad; thoracic sternal suture 3/4 usually short, only lateral but deep, and often ending as a perforation of the sternal surface; sutures $4 / 5$ to $7 / 8$ interrupted, with distant interruption points, displaying pattern 5 , subpattern 5e (Guinot et al. 2013: fig. 50C, E); male pleon with all somites free except for somite 6 that is fused with elson (pleotelson); male gonopore opening far from suture 7/8, in a posteriormost location (Guinot et al. 2013: figs. 31C, D, 50C, E); condylar protection of penis within the P5 coxosternal condyle, the penis emerging from the condyle's extremity as e.g. in Stenorhynchus or from its anterior border as e.g. in Leurocyclus, Paulita and Esopus (Guinot et al. 2013: 87, fig. 31C, D, table 4), this character needing to be checked in other genera; male pleon with deep sockets on pleotelson (Guinot et al. 2013: fig. 50D, F), corresponding to prominent buttons on sternite 5; female pleon having a maximum of six elements, the somites 5 and 6 being fused to the telson (pleotelson); in adult females, formation of a large, discoid pleonal plate and development of a brood cavity limited by a high sternal ridge, closed like a box, the pleonal margin being tightly joined to its edge, thus the need of a branchiosternal canal for oxygenation of eggs (Drach \& Guinot 1982; 1983: pl. 1, figs. 7, 9; Guinot \& Richer de Forges 1997: figs. 11E, 12E, F); pleurites regularly connected medially and with marked dorso-ventral partition due to developed junction plate; sternite 8 with basal bridge (Leurocyclus), median line absent (Esopus), or only basal (Paulita) or extending along thoracic sternite 8 (Leurocyclus); in females, forward orientation of sternite 6 leading to anterior displacement of vulvae (Guinot et al. 2013: fig. 48A). It appears that many inachoidids do not possess hooked setae or show only sparsely distributed hooked setae (near the rostrum), at least when adults, and thus do not decorate (Guinot \& Wicksten 2015).

Depending on the extension of sternite 4 , different states of the thoracic sternum/pterygostome junction are found in Inachoididae, resulting in diverse shapes of the Milne- 
Edwards openings and mxp3 coxae. The junction is absent in e.g. Paradasygyius depressus, Collodes leptocheles Rathbun, 1894, Pyromaia tuberculata (Lockington, 1876), and Leurocyclus tuberculosus (H. Milne Edwards \& Lucas, 1842), whereas it is complete, with entirely separated Milne-Edwards openings, in other species, e.g. Esopus crassus (Fig. 4A, B), Paulita tuberculata, Batrachonotus fragosus Stimpson, and Euprognatha rastellifera Stimpson, 1871, E. bifida Rathbun, 1893 (Guinot \& Richer de Forges 1997: 488, figs. 11C, 12C, D, 13A, B, 14A, B; Guinot 2012; Guinot et al. 2013: figs. 48A, 49C, E).

Dissections have shown that the axial skeleton, with the pleurites almost horizontal and regularly connecting medially, was fused to the carapace by pillars, at least in Paradasygius depressus, Paulita tuberculata and Leurocyclus tuberculosus (Drach \& Guinot 1982: pl. 1, figs. 5, 6, as Paradasygius tuberculatus; 1983: pl. 1, figs. 4, 7, 8; Guinot et al. 2013: fig. 47G-I), so that it is difficult to detach them from the carapace without breaking it. This exceptional connection, observed in inachoidids with a flattened carapace but also in those with a thicker body (e.g., Anasimus A. Milne-Edwards, 1880, Collodes Stimpson, 1860, at least pro parte), needs to be checked by dissection in all genera of Inachoididae. The exposure of the latero-external portions of pleurites $5-8$ is a unique disposition that is found in all the inachoidid taxa. It should be noted, however, that the Raninoidea De Haan, 1839 (Gymnopleura Bourne, 1922) display a partial exposure of the pleurites 5-7, with heavily calcified exposed external portions, and by forming a somewhat excavated and roughly quadrilateral area between the pereiopod coxae and the branchiostegite (Van Bakel et al. 2012).

The family Inachoididae includes the ten genera cited by $\mathrm{Ng}$ et al. (2008: 115) plus Erileptus Rathbun, 1893, and three additional genera: 1) Paulita, established for Paradasygyius tuberculatus, distinguished from Paradasygyius depressus (Guinot 2012); 2) Stenorhynchus, known by four species, traditionally assigned to the Inachidae, and transferred to the Inachoididae as a distinct subfamily, the Stenorhynchinae (Guinot 2012); 3) Esopus, in the present paper (see also Guinot 2019).

The Inachoididae is mostly a New World family, formerly known exclusively from the Atlantic and Pacific coasts of the Americas. But, with the addition of the genus Stenorhynchus, previously assigned to Inachidae and known by three American members plus a West-African species, S. lanceolatus (Brullé, 1837), the distribution of the family now includes the eastern Atlantic (Madeira, Canary Is., Cape Verde Is., and numerous west-African localities from Western Sahara to Angola). Another exception is the invasive species Pyromaia tuberculata, now successfully established in several distant regions, see Galil et al. (2011).

The monophyly of Inachoididae has been recovered by an outstanding morphological cladistic 
analysis (Santana 2008: 221). In a re-evaluation of larval support for the monophyly of majoid families (Marques \& Pohle 2003), Inachidae + Inachoididae (except Macrocheira) formed a monophyletic clade in unconstrained analyses, with Leurocyclus nesting as the most basal taxon of Inachidae + Inachoididae, and Inachidae being a more derived group. Larval data, however, have not provided clear synapomorphies for Inachoididae, not supporting its separation from Inachidae (Pohle \& Marques 2000; Marques \& Pohle 1998, 2003). According to Santana \& Marques (2009: 55), all inachoidids with a completely described larval development (Anasimus latus, Pyromaia tuberculata, Paradasygyius depressus) conform for the most part to the general pattern of Majoidea (two zoeal stages), Leurocyclus differing, however, from the other inachoidids by several features and from all majoids by the setal formula of the distal article of the mxp2 endopod in both zoeal stages. The larval development of Paulita tuberculata, still unknown, is predicted to be peculiar, distinctive. Currently, the Inachoididae is recognised as a valid family on the basis of morphological criteria (Melo 1996, as Inachoidinae; Coelho 2006; Ng et al. 2008; Santana 2008; Guinot 2012; Guinot et al. 2013; Davie et al. 2015a, b, c; Antunes et al. 2016, 2018; Carmona-Suárez \& Poupin 2016), also supported by molecular data (Colavite et al. 2019), and phylogenomic analyses (Wolfe et al. 2019), as well by paleontological data (Artal et al. 2012, 2014; Jagt et al. 2015).

Inachoidids have a determinate growth, i.e. at sexual maturity they cease growing in favour of reproduction (MacLay 2015: table 4).

The similarities between Inachoididae and Hymenosomatoidea MacLeay, 1838, and also with Dorippoidea MacLeay, 1838, were being interpreted as a synapomorphy relation by Guinot \& Richer de Forges (1997), Guinot (2011b) and Guinot et al. (2013). The gutter inside which the carapace lies and involving pleurites 5-7 in Dorippoidea (Guinot et al. 2013: figs. 46A, B, 47A, B) and the gutter involving pleurites 5-8 in Inachoididae (Figs. 1, 2A) are both reminiscent of the rim that entirely or partly encircles the hymenosomatid carapace dorsal surface.

\section{THE STATUS OF ESOPINAE SUBFAM. NOV. AMONG THE INACHOIDIDAE}

Esopinae subfam. nov. differs from all other Inachoididae by several characters. The most important trait is probably the junction of the developed proepistome to the epistomial process (Figs. 3A, 4A), whereas there is a hiatus between these two structures in most inachoidids, with the exception of the Paulitinae subfam. nov., in which the ventral part of the rostrum forms a thin, recessed septum (proepistome) that reaches the epistomial process. In Esopinae subfam. nov. the salient and expanded antennal basal article is close to the corresponding article of the other side (Figs. 3A, 4A), another apomorphic character of the subfamily. In fact, the esopine front, rostrum, epistome and 
cephalic appendages (Figs. 2B, C, 3A, 4A) are all synapomorphic, as well as the narrow carapace and the path of the deep grooves on carapace dorsal surface (Figs. 1, 2C). The dorsal surface is remarkably inflated, arranged in four areas: frontal (tripartite), gastric (subdivided into several swollen portions), cardiac (prominent), intestinal (flat). The short eye is well protected in the orbit formed by the thick cup-shaped postorbital tooth, subhepatic region and salient frontal edge (Fig. 2B, C). Most inachoidids do not possess orbits, the eyes being generally not protected, except for Salaciinae in which large, closed orbits are differently shaped, and Paulita in which the narrower and longer eyestalk is only partially protected by the postorbital tooth. In addition to the broadly triangular carapace, the transversal and longitudinal grooves, Paulita can be distinguished by the salient mxp3 that contrast with the flat mouthparts of Esopinae subfam. nov.; in Paulita the pentagonal shield formed by thoracic sternites $1-3$, with sternite 3 much inflated that sternites 1,2 , differs from the triangular, inflated piece formed by fused sternites 1-3 found in Esopinae subfam. nov. (Figs. 3C, 4A, B) (Chace 1940: fig. 21A). In ovigerous females of Paulita tuberculata the portion of thoracic sternum that is present in front of the wall of the brood cavity comprises a small triangular piece plus a prominent piece corresponding to the large, separate sternite 3 , whereas only a triangular shield is present in front of the wall of the brood cavity in E. crassus (Fig 3C). The laying of Esopus crassus consists of few large eggs, whereas that of P. tuberculata consists of more smaller and numerous eggs.

\section{INACHOIDID SUBFAMILIES}

The inachoidid representatives exhibit very different morphologies, some with a typically triangular majoid carapace and a developed rostrum, others not conforming to this morphotype. Other major variations concern eye protection, antenna configuration, and proepistome condition. Orbits range from shallow to moderately deep, so that small, poorly protected eyestalks are entirely visible dorsally. The vertically folded antennules are located in two fossae, separated by the bent rostrum itself (Esopus) or its ventral portion or spiniform process. The urinary article of the antenna is either adjacent to the basal article, or it is remote from the basal article and therefore sunken in the epistome. The proepistome varies from thick and clearly dorsally visible to very thin, recessed, and concealed (Leurocyclus). The epistome varies from reduced to rather large, with an anterior spiniform process that may or may not join the proepistome.

Despite these obvious divergences, the family Inachoididae was not recently subdivided, except by Števčić (2005) who recognised three tribes, in using ancient existing names (Collodini Stimpson, 1871, Inachoidini Dana, 1851, Salacini [sic] Dana, 1851), whereas later (Števčić 2013) he subordinated without explanation these three tribes to the subfamily Inachoidinae. These 
subdivisions are not currently used. However, Guinot (1984: 381) and Guinot \& Cleva (2002b: 508) had envisaged the possibility of a separate subfamily, Salaciinae Dana, 1851 to accommodate Leurocyclus. On the other hand, the existence of two larval groups has suggested that the family Inachoididae was heterogeneous (Oh \& Ko 2010: 135).

Today, and in a preliminary approach, we provisionally propose to recognise within the Inachoididae seven subfamilies, for which we provide a new description. On the available evidence, there is some support for the recognition of the four already named subfamilies but poorly documented (Collodinae Stimpson, 1871, Dasygyiinae Holmes, 1900, Inachoidinae Dana, 1851, Salaciinae Dana, 1851), plus one that was recently recognised (Stenorhynchinae Dana, 1851) (Guinot 2012). Two are new: Esopinae subfam. nov. and Paulitinae subfam. nov., both monotypic. This subfamily-level diversity of Inachoididae contrasts with the large quantity of monotypic genera, their number being about the half of the known inachoidid genera.

\section{Subfamily Collodinae Stimpson, 1871}

Collodini Stimpson, 1871: 119.

Microrhynchinae Miers, 1879: 651.

Collodini Števčić 2005: 99.

Colloidini [sic] Števčić 2013: 185.

Type genus. Collodes Stimpson, 1860 (type species by monotypy: Collodes granosus Stimpson, 1860).

Description (bsed on the type species of the type genus, $C$. granosus). Carapace subovatesubpyriform, resting on setting gutter. Dorsal surface with tubercles and spines (Rathbun 1925: pl. 36, fig. 1, pl. 217, fig. 1, Collodes granosus; Garth 1958: pl. 3, fig. 5, C. granosus; Hendrickx 1999: fig. 31A; Santana 2008: figs. 12C, 13A C. granosus). Rostrum short, tip bifid (Rathbun 1925: fig. 31, pl. 217, fig. 1, C granosus). Preorbital tooth small. Postorbital tooth well developed, not detached, laterally directed, inner margin concave, curving around eye. Antenna: articles 1, 2+3 fused to epistome, urinary orifice sunken in epistome; basal article with entire carina on internal margin, external margin corsaly granulate (Garth 1958: fig. 4A, C. granosus); flagellum exposed in dorsal view. Proepistome long, laterally compressed, separated by small gap from spiniform process of epistome. Epistome approximatively as wide as long. Mxp3: merus expanded at its anteroexternal angle; crista dentata with small, acute teeth. Thoracic sternum flat, except the first three inflated sternites. Sternum/pterygostome junction incomplete, sternite 4 extended only on a short distance; Milne-Edwards openings not separated from chelipeds. Exposed pleurites 5-8 forming rather narrow collar, with crenulate margin. Male chelipeds robust, palm high; fingers 
gaping in a broad oval for basal three-fifths (Hendrickx 1999: fig. 31B). Female chelipeds weak (Rathbun 1925, pl. 36, fig. 2, C. granosus). Ambulatory legs rather depressed, hairy, dactyli with setae. Pleon: first somite dorsal, produced into small spine. Male gonopore partially condylar, partially coxal (Guinot et al. 2013: 127). Male pleon with somites 1-5 free, somite 6 being fused to telson (pleotelson); female pleon with somites 1-4 free, somites 5, 6 being fused to telson (pleotelson) (Rathbun 1925: pl. 36, fig. 2; Santana 2008: fig. 15B, C. granosus). G1: variously developed lobe with subapical aperture, cluster of long spines near tip (Garth 1958: pl. E, fig. 2, C. granosus). Pleonal-locking mechanism: button on sternite 5; socket on pleotelson.

Remarks. The genus Collodes that includes numerous species showing a variety of morphological forms is clearly paraphyeltic. It is why our description of the Collodinae is essentially based on the type species of the genus, $C$. granosus from the Pacific coast of the Americas (Hendrickx 1999: fig. 32), and will apply to it and only close genera.

The cladistic analysis of Santana (2008: 225, figs. 65, 66) did not recover a monophyletic group. Five species form a basal complex: Collodes armatus Rathbun, 1878 (Melo 1996: fig. p. 199; Santana 2008: figs. 11A, 12A); C. inermis A. Milne-Edwards, 1878 (Melo 1996: fig. p. 200; Santana 2008: figs. 12D, 16A; Santana \& Tavares 2017: figs. 1C, 2C); C. leptocheles Rathbun, 1894 (Santana 2008: figs. 17A, B, 18A, 19A; Alves-Júnior et al. 2019: fig. 4); C. levis Rathbun, 1901 (Santana 2008: figs. 19C, 20A, C); C. tumidus Rathbun, 1898 (Santana 2008: figs. 26C, 28A, C). Most of the ohers species form a polytomy: Collodes anartius Colavite, Windsor \& Santana, 2019; C. gibbosus (Bell, 1835) (Santana 2008: figs. 12B, 13A, 14B); C. granosus Stimpson, 1860 (Hendrickx 1999: fig. 31; Santana 2008: figs. 12C, 15A); C. obesus A. Milne-Edwards, 1878 (Santana 2008: figs. 19D, 21A); C. robustus Smith, 1883 (Drach \& Guinot 1983: fig. 3; Guinot \& Richer de Forges 1997: fig. 12A; Santana 2008: figs. 22B, C, 23A); C. rostratus A. Milne-Edwards, 1879 (Melo 1996: fig. p. 201; Santana 2008: figs. 23C, 24A); C. tenuirostris Rathbun, 1894 (Santana 2008: figs. 25A, C, 26A, B); C. trispinosus Stimpson, 1871 (Melo 1996: fig. p. 202; Santana 2008: fig. 27A, B); C. tuerkayi Santana \& Tavares, 2017 (Santana \& Tavares 2017: figs. 1A, 2A). See also the molecular phylogenetic tree represented as maximum likelihood topology of three mitochondrial and two nuclear genes in seven of the 15 described species of Collodes (Colavite et al. 2019: fig. 1).

Other included genera. Probably, there may be several, close to $C$. granosus, to be added in the future (see below, Status of other inachoidid genera). 
Dasygyinae Holmes 1900: 27.

Type genus. Dasygyius Rathbun, 1897, replaced by Paradasygyius Garth, 1958 (type species by original designation: Microrhynchus depressus Bell, 1835, now Paradasygyius depressus).

Description. Body markedly flattened. Carapace rounded, longer as wide, distinctly narrowing anteriorly (Garth 1958: pl. 4, fig. 2). Carapace resting on setting gutter (Drach \& Guinot 1982: pl. 1, fig. 5). Carapace dorsal surface covered with fine granulations and some occasional larger ones, with shallow grooves (Santana 2008: figs. 49A, 50A). Rostrum simple, short, as narrow triangle. Preorbital tooth absent. Postorbital tooth large, curving around eye, forming postocular cup (supraocular eave) accommodating eyestalk in resting position (Santana 2008: fig. 49A, B). Eyes large, flattened. Antenna: basal article adjacent to urinary article, long: with two teeth on inner margin, outer angle conspicuously projecting dorsally by long, narrow tooth; antennal movable portion entirely visible in dorsal view at side of rostrum (Santana 2008: figs. 49A, 50A).

Proepistome laterally compressed, forming slightly recessed septum not joining rudimentary epistome. Branchiostegite very reduced; branchial chamber reduced to narrow space due to flattening of body, probably not functional posteriorly, without gills at level of last pereiopods. Mxp3: ischium narrow, crista dentata formed by triangular teeth; merus narrow at base, then strongly cordiform; coxa short, prolonged by distal lobe to embayment (Rathbun 1925: fig. 50, as Dasygyius depressus; Guinot \& Richer de Forges 1997: fig. 14A). Thoracic sternum flat, except the first three inflated sternites (Santana 2008: fig. 49B; Guinot 2012: fig. 3C; Guinot et al. 2019: fig. 16B). Absence of sternum/pterygostome junction, sternite 4 not laterally extended; suture 3/4 short, only lateral, forming deep pocket (Guinot 2012: fig. 3C, D); Milne-Edwards openings not separated from chelipeds. Presence of very wide sternal extensions joining exposed pleurites (sternum/pleurites connections) between $\mathrm{P} 1 / \mathrm{P} 2, \mathrm{P} 2 / \mathrm{P} 3, \mathrm{P} 3 / \mathrm{P} 4, \mathrm{P} 4 / \mathrm{P} 5$. Pleurites regularly connecting medially and fused to carapace by pillars (Drach \& Guinot 1982). Pleurites 5-8 exposed, rather wide, each sclerite pointed at each end and covered with small granules (Drach \& Guinot 1982: pl. 1, fig. 5; Hendrickx 1999: fig. 2A, B; Santana 2008: figs. 49A, 50A). Male chelipeds stout; palm inflated, subglobular; fingers narrowly gaping at base, crenulate on prehensile margins (Rathbun 1925: fig. 51, as Dasygyius depressus; Garth 1958: pl. 4, fig. 2; Hendrickx 1999: fig. 40B). Female chelipeds weaker than legs, palm not swollen (Rathbun 1925: pl. 274, figs. 7-8, as Dasygyius depressus). Ambulatory legs very long, granulate and hairy (Hendrickx 1999: fig. 40A; Santana 2008: fig. 47B). Pleon: first somite dorsal, granular, produced into long, conical, acute spine in both sexes (Drach \& Guinot 1982: pl. 1, fig. 4; Santana 2008: fig. 50B). Male pleon with somites 1-5 free, somites 6 being fused to telson (pleotelson); female pleon (Rathbun 1925: pl. 274, fig. 5, as Dasygyius depressus) with somites 1-4 free, somites 5, 6 being fused to telson (pleotelson). Male 
gonopore partially condylar, partially coxal (Guinot et al. 2013: 127). G1 straight, without developed lobe, aperture subapical (Garth 1958: pl. E, fig. 5). Vulvae located on anteriorly displaced sternite 6, as expansions projecting on sternites 5 and even 4. Pleonal-locking mechanism: marked, often pointed button on sternite 5, near suture 5/6; socket on pleotelson (Guinot \& Richer de Forges 1997: fig. 14B, C).

Remarks. Based on the analysis of larval characters, Marques \& Pohle (1998) considered Paradasygyius (depressus) an inachine, as the sister taxon of Inachus Weber, 1795. Pohle \& Marques (2000) found no larval evidence to support the monophyly of Inachoidinae, and Marques $\&$ Pohle (2003: 77) were unable to provide a single synapomorphy for the Inachoididae, "with the clade (Anasimus (Paradasygyius (Collodes + Pyromaia)))" supported by some larval characters. See above The family Inachoididae.

Other included genera. None.

\section{Restricted chresonymy of Paradasygyius depressus, with illustrations}

Paradasygyius depressus Garth, 1958: 67, 68, 80.

Paradasygyius depressus Drach \& Guinot 1982: figs. 4, 5.- Guinot \& Richer de Forges 1997: fig. 14A-C.-Hendrickx 1999: 70, figs. 2A, B, 40, 41.-Santana 2008: figs. 49A, 50A.—Guinot 2012: 23-27, fig. 3C, D._-Guinot et al. 2013: 224, 229; 2019: fig. 16B.

Type data: Female holotype, originally in the Museum of the Zoological Society of London, no longer extant. Neotype, formerly in Allan Hancock Foundation (No. 398), now in Natural History Museum of Los Angeles County.

Type locality. Panama, from 10 miles southwest of Secas Islands, Velero III, station 944-39, ca 55 m, March 27, 1939 (after Garth 1958: 81).

Subfamily Inachoidinae Dana, 1851

Inachoidini Števčić, 2005: 99; 2013: 185.

Type genus. Inachoides H. Milne Edwards \& Lucas, 1842 (type species by monotypy: $I$. microrhynchus H. Milne Edwards \& Lucas, 1842; junior synonym: Inachoides lambriformis De Haan, 1839, see Holthuis 1993 (Drach \& Guinot 1983: fig. 4, as Inachoides microrhynchus; Guinot \& Cleva 2002b: 507; Santana 2008: figs. 45B, 46A; Santana \& Tavares 2009: figs. 1E, F, 2D). Other spcies: Inachoides laevis Stimpson, 1860 (Hendrickx 1999: figs. 38, 39; Santana 2008: figs. 44A, 45A); Inachoides forceps A. Milne-Edwards, 1879 (junior synonym: Podochela meloi 
Sankarankutty, Ferreira \& Cunha, 2001) (Williams 1984: figs. 234, 240; Melo 1996: fig. p. 206; Coelho 2006: 678; Santana \& Tavares 2009: 62 -68, figs. 1A-D, 2A-C).

Description. Carapace longer than wide, triangular, broad and swollen behind, anteriorly narrowing, with marked depression between orbits. Carapace resting on setting gutter. Dorsal surface with tubercles and granules, or nearly smooth except for cardiac tubercle; some inflated regions (Rathbun 1925: pl. 22, fig. 1, as Inachoides microrhynchus; Drach \& Guinot 1983: pl. 1, fig. 1, as Inachoides microrhynchus; Garth 1958: pl. 6, fig. 3, as Inachoides microrhynchus; Santana 2008: figs. 44A, 45A, B, 46A; Santana \& Tavares 2009: fig. 2: I. forceps and I.

lambriformis). Rostrum simple, short, ending in spine. Preorbital tooth absent (Hendrickx 1999: fig. 38B: I. laevis). Postorbital tooth minute or strong. Orbits entire. Antenna: articles 1, 2+3 fused to epistome, urinary orifice sunken in epistome; basal article narrow, with low carina or only granular rows; anteroexternal tooth exposed in dorsal view; flagellum exposed from its insertion.

Proepistome long, laterally compressed, not joining (small gap) advanced process of epistome. Epistome large, nearly quadrilateral. Mxp3: merus as wide as ischium, rounded at anteroexternal angle (Rathbun 1925: fig. 16); crista dentata indistinct. Thoracic sternum flat, except first three inflated sternites (Santana 2008: fig. 46B). Sternum/pterygostome junction apparently complete, sternite 4 extending by thin terminal process; lateral suture $3 / 4$ short, ending by deep depression; Milne-Edwards openings separated from chelipeds. Exposed pleurites 5-8 forming rather narrow collar, especially first two; pleurites regularly connecting medially and fused to carapace by pillars (Drach \& Guinot 1983: pl. 1, fig. 4, as Inachoides microrhynchus). Male chelipeds strong; palm swollen; fingers narrowly gaping at base (Rathbun 1925: pl. 22, figs. 1-6 as Inachoides microrhynchus and I. laevis; Hendrickx 1999: fig. 38B: I. laevis; Santana \& Tavares 2009: fig. 1A, B: I. forceps). Female chelipeds weaker than legs, palm not swollen (Santana \& Tavares 2009: fig. 1C, D: I. forceps). Ambulatory legs of moderate length, slender, with curved dactyli (Santana \& Tavares 2009: fig. 3: I. forceps). Pleon: first somite dorsal, produced into small spine or not. Male pleon with somites 1-5 free, somites 6 being fused to telson (pleotelson); female pleon (Rathbun 1925: pl. 23, figs. 3, 4) with somites 1-4 free, somites 5, 6 being fused to telson (pleotelson). G1 straight; long subapical lobe with aperture; tip sharply or broadly triangular (Garth 1958: pl. E, figs. 6, 9; Williams 1984: fig. 241i). Pleonal-locking mechanism: button on sternite 5; socket on pleotelson.

Other included genera. There may be perhepas more to be added in the future (see below, Status of other inachoidid genera).

\section{Subfamily Paulitinae Guinot \& Van Bakel, subfam. nov.}


Type genus. Paulita Guinot, 2012 (type species by monotypy: Dasygyius tuberculatus Lemos de Castro, 1949).

Description. Body moderately flat. Carapace urn-shaped, with moderate anterior narrowing, resting on setting gutter (Lemos de Castro 1949: figs. 8, 9, as Dasygyius tuberculatus; Drach \& Guinot 1982: pl. 1, fig. 1, as Paradasygyius tuberculatus; Santana 2008: figs. 50C, 51B, C, as Paradasygyius tuberculatus; Guinot 2012: figs. 1, 2A; Guinot et al. 2019: fig. 16A). Dorsal surface (Guinot 2012: figs. 1, 2A, B) divided into convex regions delineated by several parallel, deep, broad grooves: cervical groove well marked, bearing median gastric pits; branchial groove delimiting main part of branchial region; branchiocardiac groove marked. Dorsal surface uniformly covered with prominent tubercules. Lateral margins rounded, unarmed. Pleurites 5-8 (Guinot 2012: fig. 2A, B) exposed on same level as carapace, calcified, ornamented as carapace; first pleonal somite in prolongation of cephalothorax, dorsally visible, calcified, ornamented; insertion of carapace into setting gutter (Drach \& Guinot 1982: pl. 1, fig. 3, as Paradasygyius tuberculatus); branchiostegite mostly absent. Rostrum simple, broadly triangular, pentagonal (Lemos de Castro 1949: fig. 4, as Dasygyius tuberculatus), its ventral portion (proepistome) joining the epistomial process.

Antennules vertically folded beneath rostrum. Eyestalk narrow. Antenna: urinary article adjacent to basal article $(2+3)$ (thus not sunken in epistome); basal article large, fused to front, unarmed; articles 4, 5 free; flagellum short (Lemos de Castro 1949: fig. 5, as Dasygyius tuberculatus). Supraorbital margin with median tooth. Exorbital tooth blunt. Pterygostomial lobe well marked (Guinot 2012: fig. 3B). Mxp3: ischium with inner margin coarsely dentate, produced into lobe at inner distal angle; merus cordiform, with outer angle slightly rounded laterally and inner angle produced; palp stocky, with carpus enlarged, three-fifths as thick as long (Lemos de Castro 1949: fig. 3, as Dasygyius tuberculatus; Guinot 2012: fig. 3B). Thoracic sternum markedly wide, inflated; anterior shield (sternites 1-3) inserted between mxp3, as a pentagonal shield; sternite 3 developed, much inflated; suture 3/4 laterally visible, continuing into depression (Santana 2008: figs. 51D, 52B, as Paradasygyius tuberculatus; Guinot 2012: figs. 2C, 3A; Guinot et al. 2019: fig. 16C). Sutures 4/5-7/8 all interrupted, with distant interruption points. Sternite 8 with basal median line, continuing by depression. Sternum/pterygostome junction complete thanks to curved extension of sternite 4. Milne-Edwards openings separated from chelipeds, large, entirely filled by mxp3 coxa (Guinot 2012: fig. 3B). Wide sternal extensions joining exposed pleurites (sternum/pleurites connections) between P1/P2, P2/P3, P3/P4, P4/P5 (Guinot 2012: figs. 2C, 3A). Sternal device for pleonal-locking system represented by 2 or several granules disposed between sutures 4/5, 5/6; pleonal edge of somites 4-6 markedly thickened, ending in deep socket. Male, female pleons with first somite developed, entirely dorsally visible, ornamented like carapace, not produced into spine. 
Male pleon (Lemos de Castro, 1949: fig. 6, as Dasygyius tuberculatus; Guinot 2012: figs. 2C, 3A) with all somites free, except for somite 6 fused to telson (pleotelson); somite 1 narrow but high; somites 2, 3 widened; somites 4, 5, pleotelson narrow; pleotelson base laterally inflated at location of sockets. Female pleon (Lemos de Castro 1949: fig. 7, as Dasygyius tuberculatus; Guinot 2012: fig. 2D) with somites 1-4 free, not high; somites 5, 6 fused to pleotelson, forming large, flat or convex disc, inserted in sterno-pleonal cavity; brood cavity closed like a box, limited by sternal elevated arch formed by raised sternites all around. Male chelipeds (Lemos de Castro 1949: fig. 2, as Dasygyius tuberculatus; Guinot 2012: fig. 1) equal, unarmed, with minute granules; propodus narrow, elongated, slightly inflated in larger males; fingers long, tapering, gaping in proximal half, distally joined; prehensile border finely denticulated in proximal half, distinctly toothed distally. Female chelipeds (Lemos de Castro 1949: fig. 1, as Dasygyius tuberculatus; Guinot 2012: fig. 2D) narrow, fingers joined. Pereopods long, thin, cylindrical throughout length, unarmed; P2 densely fringed with hairs in males; P2-P5 with additional setae in females (Lemos de Castro 1949: figs. 811 as Dasygyius tuberculatus; Guinot 2012: fig. 1). Coxal male gonopore large, located far from suture $7 / 8$, thus in posteriormost location; opening on anterior border of coxo-sternal condyle, thus partially condylar, partially coxal (Guinot et al. 2013: 127); penis short, emerging on lateral side of coxo-sternal condyle. G1 gently curved, with elongated, twisted lobe (Guinot-Dumortier 1960: fig. 22a-c, as Paradasygyius tuberculatus; Santana 2008: figs. 50C, 51D, as Paradasygyius tuberculatus). G2 conspicuously short. Vulvae much protruded, located on sternite 6 displaced anteriorly to suture 4/5; sternal vulvar cover developed. Axial skeleton with lateral compartment together with dorsoventral partition (developed junction plate), pleurites being almost horizontal (Guinot 2012: fig. 2B); in anterior region, dorsal edges of pleurites connected to internal surface of carapace by vertical pillars (Drach \& Guinot 1982: pl. 1, fig. 6, as Paradasygyius tuberculatus). A bridge with median line (with posteriorly et anteriorly a depression) in middle of sternite 7 (corresponding to raised median plate). Presence of thick sella turcica (Guinot et al. 2013: fig. 47G, $\mathrm{H})$.

Remarks. Paulitinae subfam. nov. may be differentiated from the Dasygiinae by a number of characters mainly related to the carapace, thoracic sternum, links between sternum and pterygostome, Milne-Edwards openings, and first gonopod.

Other included genera. None.

Restricted chresonymy of Paulita tuberculata (Lemos de Castro, 1949)

Dasygyius tuberculatus Lemos de Castro, 1949: 349-352, figs. 1-11.

Paradasygyius tuberculatus Holthuis 1959: 187, pl. 6, fig. 1._Guinot-Dumortier 1960: 180, fig. 22a-c.-Coelho 1971: 138.-Drach \& Guinot 1982: figs. 1C3, 6.-Takeda \& Okutani 1983: fig. p. 
133.-Melo 1996: fig. p. 208._Guinot \& Richer de Forges 1997: figs. 11A-E, 13A-D.—Coelho et al. 2008: 20.-Santana 2008: figs. 50C, 51B, C, 52A.

Paulita tuberculata Guinot 2012: 23-31, figs. 1, 2, 3A, B.-Guinot et al. 2013: fig. 47G, H.-Guinot et al. 2019: fig. 16A, C.-Guinot 2019: 783.

Type data. Type material is deposited in National Museum of Brazil, Rio de Janeiro (W. Santana, pers. comm., Dec. 2019).

Type locality. Brazil, Ceará, Fortaleza, Praia de Mucuripe.

Subfamily Salaciinae Dana, 1851 (as Salacinae)

Salacinae [sic] Dana, 1851: 430; 1852: 75-78, 81.-Brito Capello 1871: 264.

Salacini [sic] Števčić 2005: 99.

Salaciinae Guinot 1984: 381._-Guinot \& Cleva 2002b: 508._Guinot 2012: 30.

Salaciini Števčić 2013: 185.

Type genus. Leurocyclus Rathbun, 1897, Salacia H. Milne Edwards \& Lucas, 1842 being preoccupied by Salacia Lamouroux, 1816, a hydrozoan, and replaced by Leurocyclus (Rathbun 1897) [(type species: L. tuberculosus (H. Milne Edwards \& Lucas, 1842)]. See also Miers (1879). Although Salacia is not a valid nomen, the subfamily Salaciinae Dana, 1851 (Salacinae is an incorrect spelling of the nomen) is an available nomen that was used by Dana (1851:430), with Leurocyclus as type genus (see Drach \& Guinot 1983: figs. 6-9; Guinot 1984: fig. 1; Guinot \& Richer de Forges 1997: fig. 12B; Guinot \& Cleva 2002a: 40; 2002b: 508; Santana 2008: figs. 45C, D, 47B, C, 48A; Guinot et al. 2013: fig. 47I). An unfortunate typographical mistake in (2012) Guinot's abstract attributed the authorhip of the family to H. Milne Edwards \& Lucas, 1842, instead of Dana, 1851.

Description. Carapace much broader than long, suborbicular, depressed, dilated posterolaterally (H. Milne Edwards \& Lucas 1842: pl. 2, fig. 1, as Salacia; Rathbun 1925: pl. 233, fig. 1; Drach \& Guinot 1983: pl. 1, fig. 6; Guinot 1984: fig. 1; Melo 1996: fig. p. 207; Guinot \& Richer de Forges 1997: fig. 12B). Carapace resting on setting gutter. Dorsal surface with longitudinal carina marked by granules; regions well marked by deep grooves and ornamented (Santana 2008: figs. 45C, D, 47C). Rostrum small, narrow, subtriangular. Proepistome laterally compressed, reduced to recessed, concealed portion, not joining anterior process (a narrow septum) of rudimentary epistome (Rathbun 1925: pl. 232, fig. 6). Antennulae: both vertically folded in two fossae, without visible separation, the latter being deeply recessed Antenna: urinary article and 
basal article adjacent, seemingly fused; basal article $(2+3)$ very wide, concave, without longitudinal carina, with lateroexternal lobe (H. Milne Edwards \& Lucas 1842: pl. 2, fig. 2, as Salacia; Rathbun 1925: pl. 232, fig. 11; Guinot 1984: fig. 2; Santana 2008: fig. 48A); following articles (antennal movable portion) entirely visible in dorsal view at side of rostrum. Orbits rather large, directed forward, close to each other; preorbital tooth absent; postorbital tooth large forming postocular cup (supraocular eave) accommodating eyestalk in resting position (Santana 2008: fig. 48A). Mxp3: ischium broad, with developed crista dentata formed by strong spines; merus cordiform (H. Milne Edwards \& Lucas 1842: pl. 2, fig. 5, as Salacia; Rathbun 1925: pl. 232, figs. 8, 10). Pleurites regularly connecting medially and fused to carapace by pillars (Drach \& Guinot 1983: pl. 1, figs. 7, 8). Thoracic sternum: lateral suture $3 / 4$ short, ending as perforation of the sternal surface (Rathbun 1925: pl. 233, fig. 2); sutures 4/6-7/8 interrupted; a bridge at base of sternite 8 , then median line extending on sternite 8 . Sternite 3 forming a narrow, short extension; no sternum/pterygostome junction at level of sternite 4 (H. Milne Edwards \& Lucas 1842: pl. 2, fig. 8, as Salacia; Guinot 1979: pl. 16, figs. 5, 6; Santana 2008: fig. 47D). Milne-Edwards openings not separated from chelipeds. Sternal extensions joining exposed pleurites (sternum/pleurites connections) between pereiopods. Pleurites 5-8 exposed but proportionally small and narrow, each pointed at each end (thus collar with festooned appearance), ornamented (Drach \& Guinot 1983: pl. 1, fig. 6; Guinot 1984: fig. 1; Santana 2008: fig. 47B, C). Male chelipeds very short; palm swollen; fingers long, slightly curved, inner margins denticulate (Rathbun 1925: pl. 232, fig. 9; Santana 2008: fig. 47A, B). Ambulatory legs very long, spinulous; merus subcylindrical; propodus compressed; dactylus long, slender, compressed, slightly curved (Rathbun 1925: pls. 82, 83, pl. 233, fig. 1; Guinot 1984: figs. 3, 4; Santana 2008: fig. 47B). Pleon: only first somite dorsal, well developed. Male pleon with somites 1-5 free, somite 6 being fused to telson (pleotelson); female pleon with somites 1-4 free, somites 5, 6 being fused to telson (pleotelson). Male gonopore partially condylar, partially coxal (Guinot et al. 2013: 127, fig. 31C). G1 as straight, simple plate, with apical aperture (Garth 1968: pl. T, fig. 9). Vulvae located on anteriorly displaced on sternite 6, not projecting on sternite 5. Penis emerging from coxo-sternal condyle's extremity.

Other included genera. None.

Remarks. H. Milne Edwards \& Lucas (1842: pl. 2, figs. 1-8; 1843: 12, as Salacia tuberculosa) based the species on three specimens collected by A. d'Orbigny (see Guinot \& Cleva 2002a, 2002b) and diagnosed it by a practically circular carapace and a short, narrow rostrum. Both nomina Salacia and Salacinae were used by Brito Capello (1871: 263, 264, pl. 3, fig. 3, 3a), then not used for a long time.

An unconstrained analysis of larval characters of Leurocyclus tuberculosus suggested that it 
was the most basal taxon of Inachidae + Inachoididae (Marques \& Pohle 2003: 76, figs. 1A, 2). The larval morphology of L. tuberculosus conforms to the general pattern found in Majoidea, but the two zoeal stages and the megalopa differs from those of all known inachoidids by a series of characters (Marques \& Pohle 2003; Santana \& Marques 2009). All this supports the separation of the genus in its own subfamily. Leurocyclus tuberculosus, as other inachoidids, is a determinate growth crab, but growth patterns differ beween the sexes (MacLay 2015).

The biology of Leurocyclus granulosus is well studied (Barón et al. 2009; Stauffer et al. 2011; González-Pisani et al. 2011, 2017). According to González-Pisani et al. (2017), the integrated analysis of size at maturity and size frequency distributions showed that in both sexes molt to gonadal, morphological, morphometric, and functional sexual maturity occurred in advance of the terminal molt, in contrast with patterns observed in other Majoidea.

\section{Subfamily Stenorhynchinae Dana, 1851}

Stenorhynchinae Dana, 1851: 432; 1852: 83.

Stenorhynchinae Guinot 2012: 32.-- Števčić 2013: 185.-Davie et al. 2015b: 949; 2015c: 1093. _Bezerra \& Pachelle 2016: 212._Carmona-Suárez \& Poupin 2016: 366.

Type genus. Stenorhynchus Lamarck, 1815 [type species by designation by Rathbun (1897): Cancer seticornis Herbst, 1788].

Description. Carapace longer than broad, narrow, not sculpted, smooth, naked or minutely pubescent. Rostrum unpaired, very long, longer than carapace, very slender, with spinous margins. Orbits completely absent; only small postocular spine, distant from unprotected eye, situated along long 'neck'. Basal article of antenna slender, convex ventrally, not longitudinally sulcate; flagellum concealed beneath rostrum. Orbits not defined. Postorbital spine small. Proepistome not completely reaching short epistomial process. Epistome very large. Pleurites 5-8 exposed but relatively small (particularly pleurite 5), forming narrow, smooth, interrupted collar, never expanded nor salient. Carapace partially resting on weak setting gutter. First pleonal somite encroaching on concave posterior carapace margin; first, second pleonal somites integrated into cephalothorax of males; in adult females pleonal somites $1-4$, portion of 5 in prolongation of carapace, dorsally visible. Thoracic sternal suture 3/4 only weakly visible laterally, not marked by deep depression. Sternum/pterygostome junction complete. Sternal extensions from P1-P4 connecting to sternum. Chelipeds long, narrow, cylindrical. P2-P5 long, spinous (Hendrickx 1999: fig. 26B: S. debilis). Male pleon with 6 somites (pleotelson); first and seemingly second somites integrated into 
cephalothorax; female pleon with 5 somites, somites 1-4 and a portion of somite 5 in the prolongation of the carapace, visible dorsally. Male gonopore at extremity of coxo-sternal condyle (Guinot 2012; Guinot et al. 2013: fig. 31D). G1 with lobe and aperture subdistal, with setae (Brocchi 1875: pl. 19, fig. 17; Monod 1956: fig. 839; Garth 1958: pl. B, fig. 7; Williams 1984: fig. 2410).

\section{Other included genera. None.}

Remarks. Stenorhynchus occupies a quite distinct position among the Inachoididae and therefore deserves a special status in the family (Guinot 2012: 31; Guinot et al. 2013: 225). The exposed pleurites do not show the continuous collar as in other inachoidids, the exposed pleurites appearing more as sclerites as in Inachidae. The expansion of the pleurites seems already present in the first crab stage of S. seticornis (Yang 1976: fig. 7A). Complete larval development of $S$. lanceolatus has shown affinities with other inachoidids as well as its separate status (Paula \& Cartaxana 1991), justifying the erection of its own subfamily. According to Marques \& Pohle (2003: 77) larval evidence revealed that Stenorhynchus nested basal to Inachoididae. Stenorhynchinae is the only inachoidid representative occurring outside the Western Hemisphere, namely S. lanceolatus, the 'eastern Atlantic arrow crab', that is found in the eastern Atlantic (Madeira, Canary Is., Cape Verde Is., and numerous westAfrican localities from Western Sahara to Angola) (Capart 1951: 81, fig. 25; Monod 1956: 567, figs. 838, 839; Manning \& Holthuis 1981: 304, fig. 78b). Species of Stenorhynchus are for most not decorator crabs and display a peculiar behaviour (Guinot \& Wicksten 2015: fig. 71.11.6G). Molecular sequences obtained from 42 larvae of Stenorhynchus seticornis are deposited in Gen-Bank (Brandão et al. 2016).

The family Inachoididae did not invade areas outside the Americas and did not radiate in the Old World, except S. lanceolatus.

\section{STATUS OF OTHER INACHOIDID GENERA}

The status of other inachoidid genera needs further investigations, and definitive assignations are deferred until new revisions can be made. We will give here some information.

The genus Aepinus Rathbun, 1897 [(=Apocremnus A. Milne-Edwards, 1878, pre-occupied by Apocremnus Fiber, 1858, Hemiptera; type species by monotypy: Aepinus septemspinosus (A. Milne-Edwards, 1879)], monotypic, is characterised by: carapace much longer than wide, dorsal surface with several prominent, capitate spines; rostrum short, truncate, formed of two rounded 
lobes; postorbital tooth short, remote from eyestalk; and first pleonal somite with long spine (Rathbun 1925: figs. 28, 29, pl. 32, figs. 3, 4, pl. 219, figs. 1-3; Williams 1984: figs. 227, 241c; Santana 2008: figs. 3A, C, 4A, B). A. septemspinosus was recently found in Guadeloupe (CarmonaSuárez \& Poupin 2016: 364, fig. 3H, I; Poupin 2019: 190).

The genus Anasimus A. Milne-Edwards, 1880 (type species by monotypy: Anasimus fugax A. Milne-Edwards, 1880) is paraphyletic (different shapes of carapace, lateral carapace margins, rostrum, orbital region, thoracic somites $1-4$, first pleonal somite) as supported by the cladistic analysis by Santana (2008: 229: fig. 65). A. fugax (Melo 1996: fig. p. 194; Santana 2008: figs. 4C, D, 5A) shares several characters with Erileptus spinosus Rathbun, 1893 and some species of Pyromaia Stimpson, 1871. The status of A. latus Rathbun, 1891 (Drach \& Guinot 1984: fig. 5; Melo 1996: fig. p. 195; Guinot \& Richer de Forges 1997: fig. 12D; Santana 2008: figs. 6A, B, 7A), which shares some characters with Leurocyclus tuberculosus, needs a reassessment.

The genera Arachnopsis Stimpson, 1871 [(type species by monotypy: Arachnopsis filipes Stimpson, 1871 (Williams 1984: fig. 230; Melo 1996: fig. p. 196; Santana 2008: figs. 7B, 8A)], Batrachonotus Stimpson, 1871 [(type species by monotypy: Batrachonotus fragosus Stimpson, 1871 (Williams 1984: figs. 231, 241e; Santana 2008: figs. 7C, D, 9B, D, 10A)] and Erileptus Rathbun, 1893 [(type species by monotypy: E. spinosus Rathbun, 1893) (Santana 2008: figs. 29A, 30A, 31A, C)] are monotypic.

The genus Euprognatha Stimpson, 1871 (type species by monotypy: Euprognatha rastellifera Stimpson, 1871) is paraphyletic, with a group formed of E. rastellifera Stimpson, 1871 (Williams 1984: fig. 233; Santana 2008: figs. 39B, C, 40A, B, 41A, 42A; Santana \& Tavares 2008: figs. 4A-D, 6C, D), E. granulata Faxon, 1893 (Santana 2008: figs. 38A, 39A; Santana \& Tavares 2008: figs. 3C, 6A), and E. limatula Santana \& Tavares, 2008 (Melo 1996: fig. p. 205; Santana \& Tavares 2008: figs. 1B, C, E, 2A, 3D, 6B). Another group comprises E. gracilipes A. MilneEdwards, 1878 (Guinot \& Richer de Forges 1997: fig. 15F; Santana 2008: figs. 35A, C, 36A, C, 37A, B, D; Santana \& Tavares 2008: fig. 3B, 5B), and E. bifida (Guinot \& Richer de Forges 1997: fig. 12C; Hendrickx 1999: figs. 36, 37; Santana 2008: figs. 32A, 33A, 34A, C, D; Santana \& Tavares 2008: figs. 3A, 5A). Batrachonotus nicholsi Rathbun, 1894 (Garth 1958: 63-65; Drach \& Guinot 1983: fig. 2) could be a junior synonym of E. bifida.

The genus Pyromaia [(type species by monotypy: Pyromaia cuspidata Stimpson, 1871) (Williams 1984: figs. 239, 241m; Santana 2008: figs. 54C, 57A, B)] is paraphyletic. According to the cladistic analysis of Santana (2008: figs. 65, 66), P. tuberculata (Lockington, 1877) (Melo 1996: fig. p. 209; Hendrickx 1995: figs. 42, 43; Santana 2008: figs. 60A-C, 61A-B, 62A-D, 63AB, 64A-D) is apart from the others species, e.g., P. acanthina Lemaitre, N. H. Campos \& 
Bermúdez, 2001 (Santana 2008: figs. 53A, 54A), P. arachna Rathbun, 1924 (Santana 2008: figs. 54B, 55B, C, 56A, B), and P. propinqua Chace, 1940 (Santana 2008: figs. 58A, 59A, B). Note that P. vogelsangi Türkay, 1968 was considered a junior synonym of Anasimus latus by Santana (2008: $26,28)$.

\section{Fossil Inachoididae}

Is the hard and often ornamented collar all around the carapace posterolateral lateral borders, formed by the exposed distal portions of the pleurites 5-8 and the first pleonal somite, a structure that can be preserved during the taphonomic process that often results in disarticulation, separation and loss of diverse structures? As this collar is the continuation of the internal pleurites that are a part of the axial skeleton, fossilised specimens that preserve articulated remains of the ventral side and pereiopods could well preserve the collar. Actually, depending from preservation, this collar could lead to misinterpretation of the carapace outline.

Fossils assigned to Inachoididae are are rather scarce. The Recent invasive species Pyromaia inflata has been recorded by Collins \& Morris (1978) from the early Eocene of Pakistan and assigned to the Inachinae (Collins \& Morris 1978: pl. 116, figs. 7-9): the thoracic sternum is preserved; the carapace does not clearly show the special configuration of posterolateral margins, but, note, however, this is a feature difficult to discern on the small photograph of an incomplete specimen.

Eoinachoides senni Van Straelen, 1933, reported from the Upper Eocene of Venezuela (Van Straelen 1933: fig. 3) shows an outline that is not convincing. But Feldmann \& Schweitzer (2004: fig. 2A, B) illustrated a nearly complete carapace and thoracic sternum of a specimen from this Van Straelen Collection from Venezuela in Brussels: it exhibits the carapace border flanked by the typically exposed pleurites, which confirms that E. senni is a true inachoidid; in addition, the wide thoracic sternum is rather similar to that of the extant Paradasygyus depressus figured by Santana (2008: fig. 49B) and by Guinot (2012: fig. 3C). Feldmann \& Schweitzer (2004) considered that the probable age of E. senni was quite probably early Miocene instead of late Eocene. E. senni, again found by Aguilera et al. (2010: fig. 6.3.4) from the middle to upper Eocene of Venezuela, conforms to the preceding: the general shape of carapace and the eye in a postocular cup also resemble to Paradasygyus. Eoinachoides sp. reported by Aguilera et al. (2010: fig. 6.3.5, 6) from the lower Miocene of another Formation of Venezuela is less preserved. Artal et al. (2014) have compared Eoinachoides to Planobranchia Schweitzer \& Feldmann, 2010, which they asigned to the Inachidae, while it was previously assigned to Majinae by Schweitzer \& Feldmann (2010). Planobranchia indeed can be tentatively assigned to the Inachidae, in contrast to some other Eocene 
majoids such as Tumidomaia Feldmann, Schweitzer, Bennett, Frantescu, Resar \& Trudeau, 2011, and Micromaia Bittner, 1875, which seem, with all reservations, to represent Majinae.

Vicetiulita granulata De Angeli \& Ceccon, 2015, from the early Eocene (Ypresian) of Monte Magrè, northern Italy (De Angeli \& Ceccon 2015: fig. 2:1, 2), does not seem to show the typical inachoidid carapace border but however reminds the carapace of Paradasygyius depressus (see Guinot 2012) with which it has been related by De Angeli \& Ceccon (2015). Euprognatha ricei Blow, 2003, from the Upper Pliocene of southeastern Virginia and assigned to the Inachinae (Blow 2003: 181, fig. 6), is well-preserved, with cuticle, and seems to form an entire carapace, thus no likely exposure of pleurites; the posterior (?intestinal) spine on the carapace may appear to belong to the first pleonal somite, but it seems to be only an appearance, and this spine seems to be part of the actual carapace. The identification of this fossil to the inachoidid genus Euprognatha remains somewhat doubtful.

The oldest known inachoidid members were reported from the early Eocene according to Schweitzer et al. (2010) and Jagt et al. (2015), but the more reliable fossil member (Eoinachoides senni) was only recorded from the lower Miocene onwards (Feldmann \& Schweitzer 2004). In addition, it would be interesting to know if the Inachoididae, with Recent members exclusively reported from the Americas (except Stenorhynchus), has fossil representatives in the Old World.

\section{Remarks on the exposure of pleurites and the gymnopleurity in brachyuran taxa}

The gymnopleurity, i.e. the exposure of posterior pleurites beyond the carapace's margin, is a unique organisation that occurs, to varying extents, in some brachyuran taxa. It has been overlooked by most carcinologists and, yet, this exceptional arrangement was particularly notable and easily discernible in several species of Majoidea figured by A. Milne-Edwards (1873-1880) on plates 32-35. Many of these gymnopleure majoids show a particular and unique arrangment, neither noticed nor discussed by most authors (Rathbun 1925; Garth 1958), and highlighted by Drach \& Guinot $(1982,1983)$ and Guinot (2012) and that is an apomorphy of the family Inachoididae: the exposure of lateral regions of the pleurites 5-8 in the form of a collar (including the first pleonal somite) along the posterior half of the carapace, and the 'setting gutter' on which rests the carapace.

Other majoids exhibit a partial exposure of certain pleurites. The Inachidae, at least Inachus Weber, 1795, represented by its type species I. phalangium (Fabricius, 1775) and its strictly closely allied genera, differs from the Inachoididae by having a variable number of pleurites with exposed latero-external parts that only form small sclerites, instead of the 
inachoidid collar. In Cyrtomaia Miers, 1885 (type species: Cyrtomaia murrayi Miers, 1886), pleurites 5-7 extend somewhat beyond the carapace as triangular sclerites at the P2-P4 coxae levels; pleurite 5 only extends as a single pointed sclerite posterior to the P2 coxa; the pointed portions of the exposed pleural sclerites 5 and 6 on each side of the corresponding coxae (P2, P3) result from the markedly concave margins of the calcified distal parts of these pleurites, of which only the extremity of each side extends beyond the carapace's edge. Only the posterior portion of pleurite 5 is exposed, at the P2 level; pleurite 8 is only exposed by the small sclerite bearing the P5 coxo-pleural condyle, which fits into a deep gynglyme; the sclerite that partially encircles the P5 arthrodial cavity is narrower than in Inachus. Only a faint gutter receives the carapace's edge in Cyrtomaia.

In the Majinae Samouelle, 1819, exemplified by Maja Lamarck 1801, pleurites 6 and 7 slightly extend beyond the carapace by showing as triangular sclerites at the P3, P4 coxae levels; pleurite 5 only extends as a single triangular sclerite posterior to the $\mathrm{P} 2$ coxa; the small pleurite 8 is covered by the carapace, with only the P5 pleuro-coxal sternal exposed. As in Cyrtomaia the pointed shape of the exposed pleural sclerite on each side of the coxa depends on the markedly concave margins of the external part of the pleurite, of which only the angular extremity extends beyond the carapace edge. In Maja, however, the carapace does not lie inside a gutter, and pleurite 8 does not encircle the P5 arthrodial cavity.

The Cymonomidae (Bouvier, 1897 (superfamily Cyclodorippoidea Ortmann, 1892) shows a lateral exposure of the pleurites at the P2 and P3 levels (Tavares 1993: 264, key).

The most developed gymnopleurity, briefly mentioned by H. Milne Edwards (1851: 62) in Ranina Lamarck, 1801, and highlighted by Bourne (1922) in a remarkable study, is present in the Raninoidea De Haan, 1839, to such an extent that the pleurites 5-7 are laterally exposed below the branchiostegite; they are therefore not visible in dorsal and ventral views (Van Bakel et al. figs. 42D, 43, 46, 62; Guinot et al. 2013: fig. 38B, C). The hypothesis is that the adaptation of raninoids to a highly specialised burying has brought about the lifting of the carapace, and such a lifting has resulted, among other adjustments, in gymnopleurity, thus extending the body's depth and forming a specialised plate for the respiratory current (for detailed hypothesis, see Van Bakel et al. 2012: 170). Note that the basal Gymnopleura Bourne, 1922, i.e. the Palaeocorystoidea Lörenthey in Lőrenthey \& Beurlen 1929, have no exposed pleurites.

In Dorippidae H. Milne Edwards, 1837, the pleurites 5-7 have their latero-external portions exposed (Guinot et al. 2013: figs. 46A, B, 47A, B). These exposed pleural sclerites, on which each pereiopod articulates by its coxo-pleural condyle, are seemingly parts of the 
carapace because of similar ornamentation. No pleural sclerite (sclerite 8) is exposed at the P5 level, which is dorsally oriented and used for carrying behaviour; the exposed sclerite 7 (at the P4 level), which is obliquely oriented, receives the carapace edge; the exposed sclerite 6 is traversed by a gutter inside of which the carapace edge lies, the gutter remaining concealed. The anterior part of the pleurite 5 is partially exposed at the P2 level (posterior portion exposed, thus only a small sclerite 5), whereas pleurite 4 is entirely covered by the carapace at the P1 level, as it is usually the case. In Ethusidae Guinot, 1977, pleurites 5-7 extend beyond the carapace, thus have exposed latero-external portions, as in the Dorippidae, and ornamented like the carapace. Such a short setting gutter, never previously described, is unique to the Dorippoidea and therefore represents a synapomorphy of the superfamily. The setting gutter at the level of pleurites 5-8 of Inachoididae, which proceeds from a similar process, is more developed and differs by "integration" of exposed pleurites with the carapace. The branchiostegite is reduced in Dorippoidea.

It is probable that other cases of exposed pleurites occur in other brachyuran taxa, as for example in some Panopeidae Ortmann, 1893 (see Thoma \& Felder 2012).

\section{Acknowledgements}

We are pleased to acknowledge Laure Corbari (Curator of Crustacea, MNHN) for access to the collection, in particular to the material collected in 2015 by KARUBENTHOS 2 research cruise (http://dx.doi.org/10.17600/15005400) that is part if the Tropical Deep-Sea Benthos programme dedicated to the discovery of the offshore tropical marine faunas. The KARUBENTHOS 2 cruise that took place between June 6-30, 2015 was conducted by the Muséum national d'Histoire naturelle (PIs Laure Corbari, Philippe Bouchet), in conjunction with the National Park of Guadeloupe and the Université des Antilles et de la Guyane, with support from Institut Ecologie et Environnement (INEE) of the French Research Council (CNRS) and the AGOA Marine Sanctuary. Station data and further documents on the cruise are available from http://expeditions.mnhn.fr/campaign/karubenthos2015. The first KARUBENTHOS expedition in 2012 focused on the near-shore in the 0-50 meters depth range. The KARUBENTHOS 2 reveals an amazing brachyuran biodiversity, such as very rare Majoidea, including Esopus crassus. We thank Joseph Poupin and Laure Corbari, the collectors of the small majoid crab studied here, for their photographs of the material, and Paula Martin-Lefèvre for the collection data. The photographs of the male were kindly made by Ferran Palero (Centro de Estudios Avanzados de Blanes, CEAB-CSIC, Spain); the 
photographs of the female were prepared for the paper by Marie Hennion (e-ReColNat, ANR11-INBS-0004). This work greatly benefited from the helpful comments and useful suggestions of the two reviewers.

\section{References}

Aguilera, O., Rodrigues de Aguilera, D., Vega, F.J. \& Sánchez-Villagra, M. (2010) Mesozoic and Cenozoic decapod crustaceans from Venezuela and related trace-fossils assemblages. In: Sánchez-Villagra, M.R., Aguilera, O. \& Carlini, A.A. (Eds.), Urumaco and Venezuelan paleontology. The fossil record of the northern Neotropics. Indiana University Press, Bloomington, 103-128.

Ahyong, S.T., Mitra, S. \& Ng, P.K.L. (2019) Redescription of Echinoplax rubida Alcock, 1895, a valid species of Pleistacantha from the Andaman Sea (Crustacea: Brachyura: Oregoniidae). Raffles Bulletin of Zoology, 67, 391-395.

Alves-Júnior, F.A., Lucatelli, D., Santana, W. \& Souza-Filho, J.F. (2019) First record of two rare spider crabs (Crustacea: Decapoda: Brachyura: Majoidea) from Brazil. Zootaxa, 4688(1), 111-118.

Antunes, M., Zara, F.J., López-Greco, L.S. \& Negreiros-Fransozo, M.L. (2016) Morphological analysis of the female reproductive system of Stenorhynchus seticornis (Brachyura: Inachoididae) and comparisons with other Majoidea. Invertebrate Biology, 135(2), 75-86.

Antunes, M., Zara, F.J., López-Greco, L.S. \& Negreiros-Fransozo, M.L. (2018) Male reproductive system of the arrow crab Stenorhynchus seticornis (Inachoididae). Invertebrate Biology, 137(2), 171-184.

Artal, P., Van Bakel, B.W.M. \& Onetti, A. (2014) A new inachid crab (Brachyura, Majoidea) from the Middle Eocene of the provinces of Barcelona and Girona (Catalonia, Spain). In: Fraaije, R.H.B., Hyžný, M., Jagt, J.W.M., Krobicki, M. \& Van Bakel, B.W.M. (Eds.), Proceedings of the 5th Symposium on Mesozoic and Cenozoic Decapod Crustaceans, Krakow, Poland, 2013: A tribute to Pál Mihály Müller. Scripta Geologica, $147,153-161$.

Artal, P., Van Bakel, BW.M., Fraaije, R.H.B., Jagt, J.W.M. \& Klompmaker, A.A. (2012) New Albian-Cenomanian crabs (Crustacea, Decapoda, Podotremata) from Monte Orobe, Navarra, northern Spain. Revista Mexicana de Ciencias Geológicas, 29, 398410. 
Balss, H. (1929) Decapoden des Roten Meeres. IV. Oxyrhyncha und Schlussbetrachtungen. (Expedition S. M. Schiff "Pola" in das Rote Meer. Zoologische Ergebnisse 36.). Denkschriften der Kaiserlichen Akademie der Wissenschaften/MathematischNaturwissenschaftliche Classe, 102, 1-30.

Barón, P.J., Quiroga, P., Leal, G. \& González-Pisani, X. (2009) Morphological maturity of the spider crab Leurocyclus tuberculosus (H. Milne Edwards and Lucas, 1842) (Majidae, Brachyura) in the northern Patagonian gulfs. Crustaceana, 82(3), 267-273. doi:10.1163/156854008X390407.

Bezerra, L.E.A. \& Pachelle, P. (2016) Avaliação do Caranguejo Stenorhynchus seticornis (Herbst, 1788) (Decapoda: Inachoididae). Cap. 17: p. 212-220. In: Pinheiro, M. \& Boos, H. (Org.), Livro Vermelho dos Crustáceos do Brasil: Avaliação 2010-2014. Porto Alegre, RS, Sociedade Brasileira de Carcinologia - SBC, 466 p.

Blow, W.C. (2003) New brachyuran crabs (Crustacea: Decapoda) from the Upper Pliocene Yorktown Formation of southeastern Virginia. Proceedings of the Biological Society of Washington, 116(1), 168-189.

Bourne, G.C. (1922) The Raninidæ: a study in carcinology. Journal of the Linnean Society of London, 35 (Zoology, no. 231), 25-79.

Brandão, M.C., Freire, A.F. \& Burton, R.S. (2016) Estimating diversity of crabs (Decapoda: Brachyura) in a no-take marine protected area of the SW Atlantic coast through DNA barcoding of larvae. Systematics and Biodiversity 14: 288-302.

Brito Capello, F. de (1871) Descripção de algumas especies novas de crustâceos. Jornal de Sciencias mathematicas, physicas e naturales (Lisboa) 12, 262-265 (1-4).

Brocchi, P. (1875) Recherches sur les organes génitaux mâles des Crustacés Décapodes. Annales de Sciences naturelles (Zoologie), (6)2, 1-131.

Cano, G. (1893) Sviluppo e morfologia degli Oxyrhynchi. Mitteilungen aus der zoologischen Station zu Neapel (Berlin), 10, 527-583.

Capart, A. (1951) Crustacés Décapodes Brachyures. Expédition Océanographique Belge dans les Eaux Côtières Africaines de I'Atlantique Sud (1948- 1949). Résultats Scientifiques, 3(1), 11-205.

Carmona-Suárez, C. \& Poupin, J. (2016) Majoidea crabs from Guadeloupe Island, with a documented list of species for the Lesser Antilles (Crustacea, Decapoda, Brachyura, Majoidea). Zoosystema, 38(3), 353-387. https://doi.org/10.5252/z2016n3a5 
Chace, F.A. (1940) Reports on the scientific results of the Atlantis expeditions to the West Indies, under the joint auspices of University of Havana and Harvard University. The Brachyuran crabs. Torreia, 4, 1-65.

Clark, P.F. \& Webber, W.R. (1991) A redescription of Macrocheira kaempferi (Temminck, 1836) zoeas with a discussion of the classification of the Majoidea Samouelle, 1819 (Crustacea, Brachyura). Journal of Natural History, 25, 1259-1279.

Coelho, P.A. (1971) Nota prévia sobre os Majidae do Norte e Nordeste do Brasil (Crustacea, Decapoda). Arquivos do Museu Nacional, 54, 137-143.

Coelho, P.A. (2006) Revisão de Podochela Stimpson e gêneros afins nas costas caribenha e atlântica da América do Sul (Crustacea, Decapoda, Inachidae). Revista Brasileira de Zoologia, 23(3), 678-691.

Coelho, P.A., Almeida, A.O. \& Bezerra, L.E.A. (2008) Checklist of the marine and estuarine Brachyura (Crustacea: Decapoda) of northern and northeastern Brazil. Zootaxa, 1956, 1-58.

Colavite, J., Windsor, A. \& Santana, W. (2019) Three new species and a new genus of majoid crabs from the eastern Pacific (Decapoda, Brachyura). ZooKeys, 825, 1-24.

Collins, J.S.H. \& Morris, S.F. (1978) New Lower Tertiary crabs from Pakistan. Paleontology, 21(4), 957-981.

Crosnier, A. (1967) Remarques sur quelques Crustacés Décapodes benthiques ouest-africains: description de Heteropanope acanthocarpus et Medaeus rectifrons spp. nov. Bulletin du Muséum national d'Histoire naturelle (Paris), séries 2, 39(2), 320-344,

Dana, J.D. (1851) On the classification of the Maioid Crustacea or Oxyrhyncha. American Journal of Science and Arts, ser. 2, 11, 425-434.

Dana, J.D. (1852) Crustacea. United States Exploring Expedition during the years 1838, 1839, 1840, 1841, 1842 under the command of Charles Wilkes, U.S.N. Vol. 13, part 1: i-viii, 1-685. Atlas (1855), pp. 1-27, pls. 1-96.

Dana, J.D. (1853) On the classification and geographical distribution of Crustacea. From the Report on Crustacea of the United States Exploring Expedition, under Capitain Charles Wilkes, U.S.N., during the years 1838-42. C. Sherman, Philadelphia: 1395-1592, 1 map.

Davie, P.J.F., Guinot, D. \& Ng, P.K.L. (2015a) Anatomy and functional morphology of Brachyura (Chapter 71-2). In: Castro, P., Davie, P.J.F., Guinot, D., Schram, F.R. \& von Vaupel Klein, J.C. (Eds.), Decapoda:Brachyura, Treatise on Zoology-Anatomy, Taxonomy, Biology. Vol. 9C-1, Crustacea. Brill, Leiden and Boston: 11-163.

Davie, P.J.F., Guinot, D. \& Ng, P.K.L. (2015b) Phylogeny of Brachyura (Chapter 71-16). In: Castro, P., Davie, P.J.F., Guinot, D., Schram, F.R. \& von Vaupel Klein, J.C. (Eds.), 
Decapoda:Brachyura, Treatise on Zoology - Anatomy, Taxonomy, Biology.Vol. 9C-2, Crustacea. Brill, Leiden and Boston: 921-979.

Davie, P.J.F., Guinot, D. \& Ng, P.K.L. (2015c) Systematics andclassification of Brachyura (Chapter 71-18). In: Castro, P., Davie, P.J.F., Guinot, D., Schram, F.R. \& von Vaupel Klein, J.C. (Eds.), Decapoda: Brachyura, Treatise on Zoology - Anatomy, Taxonomy, Biology. Vol. 9C2, Crustacea. Brill, Leiden and Boston: 1049-1130.

De Angeli, A. \& Ceccon, L. (2015) New brachyuran crustaceans from the Eocene of Monte Magrè (Vicenza, northern Italy). Lavori Società Veneziana di Scienze Naturali, 40, $119-138$.

Drach, P. \& Guinot, D. (1982) Connexions morphologiques et fonctionnelles d'un type nouveau dans le squelette des Brachyoures du genre Paradasygius [sic] Garth (carapace, pleurites, sternites, pléon). Comptes rendus hebdomadaires des Séances de l'Académie des Sciences, sér. 3, 295, 715-720.

Drach, P. \& Guinot, D. (1983) Les Inachoididae Dana, famille de Majoidea caractérisée par des connexions morphologiques d'un type nouveau entre carapace, pleurites, sternites et pléon (Crustacea Decapoda). Comptes rendus hebdomadaires des Séances de l'Académie des Sciences, sér. 3, 297, 37-42.

Feldmann, R. \& Schweitzer, C.E. (2004) Decapod crustaceans from the lower Miocene of northwestern Venezuela (Cerro La Cruz, Castillo Formation). Special Papers in Palaeontology, 71(71), 7-22.

Forest, J. (1959) Campagne de la Calypso dans le Golfe de Guinée et aux iles Principe, Sao Tome, Annobon (1956). Annales de I'lnstitut Océanographique (Monaco), 37, 1-36.

Forest, J. \& Guinot, D. (1966) Crustacés Décapods: Brachyoures. Campagne de la Calypso dans le Golfe de Guinée et aux îles Principe, São Tomé et Annabon (1956). 16. Résultats scientifiques des campagnes de la Calypso. Introduction, 1. Annales de l'Institut océanographique (Monaco), 44, 23-124.

Fransozo, A. \& Negreiros-Fransozo, M.L. (1997) Larval stages of Pyromaia tuberculata (Lockington, 1877) (Decapoda, Majidae, Inachinae) reared in the laboratory. Crustaceana, 17(3), 304-323.

Galil, B., Clark, P.F. \& Carlton, J.T. (2011) (Eds.) In the Wrong Place - Alien Marine Crustaceans: Distribution, Biology and Impacts. Invading Nature. Springer Series in Invasion Ecology 6. Springer, Dordrecht, Heidelberg, London, New York, 716 pp.

Garcia-Isarch, E. \& Muñoz, I. (2015) Biodiversity and biogeography of decapod crustaceansin the Canary current large marine ecosystem. In: Valdés, L. \& 
Déniz- González, I. (Eds), Oceanographic and biological features in the Canary Current Large Marine Ecosystem. IOC- UNESCO, IOC Technical Series, Paris: 257-271. http://hdl.handle.net/1834/9193. 2015

Garth, J.S. (1958) Brachyura of the Pacific coast of America, Oxyrhyncha. Allan Hancock Pacific Expeditions, 21(1), xxii + 499; (2), 501-854, pls. A-Z4, 1-55.

González-Pisani, X., Barón, P.J. \& López Greco, L.S. (2011) Functional anatomy of the female reproductive systems of two spider crabs (Decapoda, Majoidea). Invertebrate Biology, 131(1), $61-74$.

González-Pisani, X., Barón, P.J. \& López Greco, L.S. (2017) Integrated analysis of sexual maturation through successive growth instars in the spider crab Leurocyclus tuberculosus (Decapoda: Majoidea). Canadian Journal of Zoology, 95, 473-483. dx.doi.org/10.1139/cjz-2016-0034

Guinot, D. (2011a) Odiomarinae nov. subfam., a new subfamily for two primitive genera of the Hymenosomatidae MacLeay, 1838 (Crustacea, Decapoda, Brachyura). Zootaxa, 2732, 20-32.

Guinot, D. (2011b) The position of the Hymenosomatidae MacLeay, 1838, within the Brachyura (Crustacea, Decapoda). Zootaxa, 2890, 40-52.

Guinot, D. (2012) Remarks on Inachoididae Dana, 1851, with the description of a new genus and the resurrection of Stenorhynchinae Dana, 1851, and recognition of the inachid subfamily Podochelinae Neumann, 1878 (Crustacea, Decapoda, Brachyura, Majoidea). Zootaxa, 3416, $22-40$.

Guinot, D. (2019) New hypotheses concerning the earliest brachyurans (Crustacea, Decapoda, Brachyura). Geodiversitas 41(22): 747-796. https://doi.org/10.5252/geodiversitas2019v41a22. http://geodiversitas.com/41/22.

Guinot, D. \& Bouchard, J.-M. (1998) Evolution of the abdominal holding systems of brachyuran crabs (Crustacea, Decapoda, Brachyura). Zoosystema, 20(4), 613-694.

Guinot, D. \& Cleva, R. (2002a) D’Orbigny et les Crustacés. In: Taquet, P. (Ed.), Alcide d'Orbigny. Du Nouveau Monde... au Passé du Monde. Nathan/VUEF et Muséum national d'Histoire naturelle, Paris: 35-43.

Guinot, D. \& Cleva, R. (2002b) Les Crustacés récoltés par d'Orbigny en Amérique du Sud et déposés au Muséum nationald'Histoire naturelle, Paris. Palevol (Paris), 1, 499-515.

Guinot, D. \& Richer de Forges, B. (1997) Affinités entre les Hymenosomatidae MacLeay, 1838 et les Inachoididae Dana, 1851 (Crustacea Decapoda Brachyura). Zoosystema, $19(2,3), 453-502$. 
Guinot, D. \& Wicksten, M.K. (2015). Camouflage: carrying behaviour, decoration behaviour, and other modalities of concealment (Chapter 71-11). In: Castro, P., Davie, P.J.F., Guinot, D., Schram, F.R. \& von Vaupel Klein, J.C. (Eds.), Decapoda:Brachyura, Treatise on ZoologyAnatomy, Taxonomy, Biology. Vol. 9C1, Crustacea. Brill, Leiden and Boston: 583-638.

Guinot, D., Carbot-Chanona, G. \& Vega, F.J. (2019) Archaeochiapasidae n. fam., a new early Cenomanian brachyuran family from Chiapas, Mexico, new insights on Lecythocaridae Schweitzer \& Feldmann, 2009, and phylogenetic implications (Crustacea, Decapoda, Brachyura, Eubrachyura). Geodiversitas, 41(7), 285-322. https://doi.org/10.5252/geodiversitas2019v41a7.

Guinot, D., Tavares, M. \& Castro, P. (2013) Significance of the sexual openings and supplementary structures on the phylogeny of brachyuran crabs (Crustacea, Decapoda, Brachyura), with new nomina for higher-ranked podotreme taxa. Zootaxa, 3665, 1-414. doi:10.11646/zootaxa.3665.1.1

Guinot-Dumortier, D. (1960) Sur une collection de Crustacés (Décapodes Reptantia) de Guyane française. II. Brachyura Oxyrhyncha et Macrura. Bulletin du Muséum national d'Histoire naturelle, Paris (2) 32 (2), 177-187.

Hendrickx, M.E. (1999) Los Cangrejos Braquiuros (Crustacea: Brachyura: Majoidea y Parthenopoidea) del Pacífico Mexicano. Comisión Nacional para el Conocimiento y Uso de la Biodiversidad (CONABIO) e Instituto de Ciencias del Mar y Limnología, UNAM, Mexico, 274 pp., 13 pls.

Henriksen, C.S. (2009) Investigation of crustaceans from shelf areas in the Gulf of Guinea, with special emphasis on Brachyura. Master. University of Bergen: 1-162.

Holmes, S. J. (1900) Synopsis of the California stalk-eyed Crustacea. Occasional papers of the California Academy of Science, 7, 1-262.

Holthuis, L.B. (1959) The Crustacea Decapoda of Suriname (Dutch Guiana). Zoologische Verhandelingen, 44, 1-296, pls. 1-16.

Holthuis, L.B. (1993) The non-Japanese new species established by W. de Haan in the Crustacea volume of Fauna Japonica (1833-1850) (with Japanese abstract by T. Yamaguchi). pp. 599-647. In: Yamaguchi, T. (Ed.), Ph. F. von Siebold and Natural History of Japan Crustacea. Carcinological Society of Japan, 731 pp., 24 pls.

Ingle, R.W. (1983) Shallow-water crabs: keys and notes of the identification of the species. In: Kermack, D.M. \& Barnes, R.S.K (Eds.), Synopses of the British Fauna No. 25. Linnean Society of London and The Estuarine and Brackish-Water Science Association, Cambridge University Press. 
Jagt, J.W.M., Van Bakel, B.W.M., Guinot, D., Fraaije, R.H. \& Artal, P. (2015) Fossil Brachyura (Chapter 71-15). In: Castro, P., Davie, P.J.F., Guinot, D., Schram, F.R. \& von Vaupel Klein, J.C. (Eds.), Treatise on Zoology - Anatomy, Taxonomy, Biology. The Crustacea, Vol. 9, Part C-II. Leiden and Boston, Brill: 847-920. https://doi. org/10.1163/9789004190832018org/10.1163/9789004190832018

Le Loeuff, P. (2001) Ecosystème benthique au large de Grand-Bassam (Côte-d'Ivoire). Considérations sur les variabilités saisonnière, interannuelle et à long terme. Document scientifique et technique, Centre IRD Bretagne, 87, 27 pp.

Le Loeuff, P. \& Intes (1998) La faune benthique associée aux fonds à crevettes pénéides (Penaeus notialis) de la Côte-d'Ivoire. Document scientifique et technique Centre Brest ORSTOM, 82, 1-160.

Lemos de Castro, A. (1949) "Dasygyius tuberculatus", uma nova espécie de Crustáceo do Brasil (Decapoda, Majidae). Revista Brasileira de Biologia, 9(3), 349-352.

MacLay, C.L. (2015) Moulting and growth (Chapter 71-5). In: Castro, P., Davie, P.J.F., Guinot, D., Schram, F.R. \& von Vaupel Klein, J.C. (Eds.), Treatise on ZoologyAnatomy, Taxonomy, Biology. The Crustacea, Vol. 9, Part C-I. Leiden and Boston, Brill: 245-316

Manning, R.B. \& Holthuis, L.B. (1981) West African brachyuran Crabs (Crustacea: Decapoda). Smithsonian Contributions to Zoology, 306, xii + 379 pp.

Marco-Herrero, A., Torres, P., Cuesta, J.A., Guerao, G., Palero, F. \& Abelló, P. (2013) The systematic position of Ergasticus (Decapoda, Brachyura) and allied genera, a molecular and morphological approach. Zoologica Scripta, 42 (4), 427-439.

Marques, F.P.L. \& Pohle, G. (1998) The use of structural reduction in phylogenetic reconstruction of decapods and a phylogenetic hypothesis for fifteen genera of Majidae: testing previous hypotheses and assumptions. Invertebrate Reproduction and Development, 33 (2-3), 241-262.

Marques, F.P.L. \& Pohle, G. (2003) Searching for larval support for majid subfamilies (Crustacea: Brachyura) with particular reference to Inachoidinae Dana, 1851. Invertebrate Reproduction and Development, 43, 71-82.

Melo, G.A.S. de (1996) Manual de Identificação dos Brachyura (Caranguejos e Siris) do Litoral Brasileiro. Plêiade/FAPESP, São Paulo, 604 pp.

Miers, E.J. (1879) On the classification of the maioid Crustacea or Oxyrhyncha, with a synopsis of the families, subfamilies, and genera. Journal of the Linnean Society (London), 14, 634-673, pls. 12, 13. 
Milne-Edwards, A. (1873-1880) Études sur les Crustacés Podophthalmaires de la région mexicaine. Mission scientifique au Mexique et dans l'Amérique centrale, ouvrage publié par ordre du Ministre de l'Instruction publique. Recherches zoologiques pour servir à l'histoire de la faune de l'Amérique centrale et du Mexique, publiées sous la direction de M. H. Milne Edwards, membre de l'Institut. Cinquième partie. Tome premier. Imprimerie nationale, Paris: 45-368, pls. 13-63.

Milne-Edwards, A. (1880) Reports on the results of dredging, under the supervision of Alexander Agassiz, in the Gulf of Mexico, and in the Caribbean Sea, 1877, '78, '79, by the United States Coast Survey Steamer Blake, Lieut.-Commander C.D. Sigsbee, U.S.N., and Commander J.R. Bartlett, U.S.N., commanding. VIII. Études préliminaires sur les crustacés. Bulletin of the Museum of Comparative Zoölogy at Harvard College, 8 (1), 1-68, pls. 1-2.

Milne-Edwards, A. \& Bouvier, E.-L. (1923) Reports on the results of dredging under the supervision of A. Agassiz, in the Gulf of Mexico (1877-78), in the Carribean Sea (1878-79), and along the Atlantic coast of the United States (1880), by the U.S. coast survey steamer Blake. XLVII. Les Porcellanides et les Brachyures. Memoirs of the Museum of Comparative Zoology at Harvard College, 47(4), 283-395, figs. 1-23, pls. $1-12$.

Milne Edwards, H. (1851) Observations sur le squelette tégumentare des Crustacés décapodes, et sur la morphologie de ces anmaux. Annales des Sciences naturelles (Zooogie), sér. 3, 16, 221-291 [1-71], pls. 8-11.

Milne Edwards, H. \& Lucas, H. (1842-1844) Crustacés. In: Orbigny, A. d' (Ed.), Voyage dans l'Amérique méridionale (le Brésil, la République orientale de l'Uruguay, la République Argentine, la Patagonie, la République du Chili, la République de Bolivia, la République du Pérou), exécuté pendant les années 1826, 1827, 1828, 1829, 1830, 1831, 1832 et 1833. Tome sixième. Première partie. P. Bertrand, Paris; Vve Levrault, Strasbourg [1842 (62): pls. 1, 3; (67): pls. 4, 6, 13; (68): pls. 2, 10; 1843 (69): 1-8, pls. 5, 7, 11; (71): 9-16, pl. 8 bis; 1844 (72): 17-24, pl. 8; (73): 25-32, pl. 7bis; (74): 33-39, pl. 9; (75): pls. 14-16; (77): pl. 17]. doi.org/10.5962/bhl.title.110540

Monod, T. (1956) Hippidea et Brachyura ouest-africains. Mémoires de l'Institut français d'Afrique Noire, 45, 1-674.

Neumann. R. (1878) Systematische Uebersicht der Gattungen der Oxyrhynchen: Catalog der Podophthalmen Crustaceen des Heidelberger Museums. J.B. Hirschfeld, Leipzig, 39 pp. 
Ng, P.K.L., Ravinesh, R. \& Ravichandran, S. (2017) A new large oregoniid spider crab of the genus Pleistacantha Miers, 1879, from the Bay of Bengal, India (Crustacea, Brachyura, Majoidea). ZooKeys, 716, 127-146. https://doi. org/10.3897/zookeys.716.21349

Ng, P.K.L., Guinot, D. \& Davie, P.J. (2008) Systema Brachyurorum: Part 1. An annotated checklist of extant brachyuran crabs of the world. Raffles Bulletin of Zoology, Supplement 17, 1-286.

Oh, S.M. \& Ko, H.S. (2010) Complete larval development of Pyromaia tuberculata (Crustacea: Decapoda: Majoidea: Inachoididae). Animal Cells and Systems, 14(2), 129136. DOI: $10.1080 / 19768354.2010 .491176$

Paula, J. \& Cartaxana, A. (1991) Complete larval development of the spider crab Stenorhynchus lanceolatus (Brullé, 1837) (Decapoda, Brachyura, Majidae), reared in the laboratory. Crustaceana, 60(2), 113-122.

Pohle, G. \& Marques, F. (2000) Larval stages of Paradasygyius depressus (Bell, 1835) (Crustacea: Decapoda: Brachyura: Majoidea) and a phylogenetic analysis for 21 genera of Majidae. Proceedings of the Biological Society of Washington, 113(3), 739-760.

Pohle, G.W. \& Telford, M. (1981) Morphology and classification of decapod crustacean larval setae: a scanning electron microscope study of Dissodactylus crinitichelis Moreira, 1901 (Brachyura: Pinnotheridae). Bulletin of Marine Science, 31, 736-752.

Poore, G.C.B. (2004) Marine Decapod Crustacea of Southern Australia. A Guide to Identification. CSIRO Publishing, Collingwood, Melbourne, 517 pp.

Poupin, J. (2018) Les Crustacés décapodes des Petites Antilles : Avec de nouvelles observations pour Saint-Martin, la Guadeloupe et la Martinique. Muséum national d'Histoire naturelle, Paris, 264 pp. (Patrimoines naturels ; 77).

Poupin, J. \& Corbari, L. (2016) A preliminary assessment of the deep-sea Decapoda collected during the KARUBENTHOS 2015 Expedition to Guadeloupe Island. Zootaxa, 4190(1), $1-107$.

Rathbun, M.J. (1897) A revision of the nomenclature of the Brachyura. Proceedings of the Biological Society of Washington, 11, 153-167.

Rathbun, M.J. (1925) The spider crabs of America. Bulletin of the U. S. National Museum, $129,1-613$.

Rossignol, M. (1962) Catalogue de Crustacés Décapodes Brachyoures, Anomoures et Macroures littoraux en collection au centre d'océanographie de Pointe-Noire. Travaux du Centre Océanographique de Pointe-Noire, 2, 111-138.

Santana, W.R.A. (2008) Revisão taxonômica e relações filogenéticas em Inachoididae Dana, 
1851 (Crustacea, Brachyura, Majoidea). Unpublished doctoral thesis, Universidade de São Paulo, 244 p.

Santana, W.R. \& Marques, F.P.L. (2009) Larval morphology of the spider crab Leurocyclus tuberculosus (Decapoda: Majoidea: Inachoididae). Nauplius, 17, 49-58.

Santana, W.R. \& Tavares, M. (2008) A new species of Euprognatha Stimpson, 1871 (Crustacea, Brachyura, Inachoididae) from off coast of northeastern Brazil. Papéis Avulsos de Zoologia (São Paulo), 48, 317-328.

Santana, W.R. \& Tavares, M. (2009) Podochela meloi Sankarankutty, Ferreira \& Cunha, 2001, a junior synonym of the spider crab Inachoides forceps A. Milne-Edwards, 1879 (Crustacea: Brachyura: Inachoididae). Zootaxa, 2294, 62-68.

Santana, W.R. \& Tavares, M. (2017) A new western Atlantic species of Collodes Stimpson (Decapoda, Brachyura, Inachoididae). Crustaceana, 90(7-10), 1145-1153.

Santana, W., Marques, F. \& Cardoso, M. Jr. (2006) Zoeal stages of Pseudomicippe varians Miers, 1879 (Decapoda: Brachyura: Majoidea: Majidae) and a comparison with other Majidae larvae. Journal of Natural History, 40(44-46), 2411-2422.

Schweitzer, C.E., Feldmann, R.M., Garassino, A., Karasawa, H. \& Schweigert, G. (2010) Systematic list of fossil decapod crustacean species. Crustaceana Monographs, 10, 1230. http://dx.doi.org/10.1163/193724012x626575

Secretan, S. (1977) Epimère et connexions épiméro-endophragmales chez les Crustacés Décapodes macroures. Bulletin de la Société Zoologique de France, 102(4), 345-374. Stauffer, T., Ostrovski, M.C., Gonçalves da Silva-Ferreira, T.C. \& Costa, T. (2011) Biology of the crab Leurocyclus tuberculosus (H. Milne Edwards \& Lucas, 1843) by catch from pink shrimp trawl fishery in the coast of Rio de Janeiro, Brazil. Nauplius, 19(1), 55-61. doi:10.1590/S0104-64972011000100006

Števčić, Z. (1994) Contribution to the re-classification of the family Majidae. Periodicum Biologorum, 96(4), 419-420.

Števčić, Z. (2005) The reclassifcation of brachyuran crabs. Natura Croatica, 14 (Suppl. 1), 1159.

Števčić, Z. (2013) Addendum to the reclassification of brachyuran crabs (Crustacea: Decapoda: Brachyura). Part II. Classification scheme. Natura Croatica, 22(1), 181-188. Stimpson, W. (1871) Preliminary report on the Crustacea dredged in the Gulf Stream in the Straits of Florida, by L. F. de Pourtales, Assist. U. S. Coast Survey. Part I. Brachyura. Bulletin of the Museum of Comparative Zoology, Harvard, 2(2), 109-160. 
Takeda, M. \& Okutani, T. (1983) Crustaceans and Mollusks trawled off Suriname and French Guiana. Japan Marine Fishery Resource Research Center, Tokyo, 354 pp.

Tavares, M. (1993) Crustacea Decapoda: les Cyclodorippidae et Cymonomidae de l'IndoOuest-Pacifique à l'exclusion du genre Cymonomus. In: Crosnier, A. (Ed.), Résultats des Campagnes MUSORSTOM, vol. 10. Mémoires du Muséum national d'Histoire naturelle, 156, 253-313.

Thoma, B. P. \& Felder, D. L. (2012) Redescription of Hexapanopeus lobipes and its reassignment to Milnepanopeus n. gen. (Decapoda: Brachyura: Panopeidae). Journal of Crustacean Biology, 32(1), 141-152.

Van Bakel, B.W.M., Guinot, D., Artal, P., Fraaije, R.H.B. \& Jagt, J.W.M. (2012) A revision of the Palaeocorystoidea and the phylogeny of raninoidian crabs (Crustacea, Decapoda, Brachyura, Podotremata). Zootaxa, 3215, 1-216.

Van Straelen, V. (1933) Sur des crustacés décapodes cénozoïques du Venezuela. Bulletin du Musée royal d'Histoire naturelle de Belgique, 9, 1-14.

Wicksten, M.K. (2008) Decapod Crustacea of the Californian and Oregonian Zoogeographic Provinces. Scripps Institution of Oceanography Library. Scripps Institution of Oceanography Library, paper 26, 413 pp. [Available from: http:// repositories.cdlib.org/sio/lib/26/ (Accessed 22 April 2013)]

Williams, A.B. (1965) Marine decapod crustaceans of the Carolinas. Fishery Bulletin 65(1), i$\mathrm{xi}-\mathrm{i}+298 \mathrm{pp}$.

Williams, A.B. (1984) Shrimps, Lobsters, and Crabs of the Atlantic Coast of the Eastern United States, Maine to Florida. Smithsonian Institution Press, Washington, D.C., 550 pp.

Wolfe, J.M., Breinholt, J.W., Crandall, K.A., Lemmon, A.R., Moriarty Lemmon, E., Timm, L.E., Siddall, M.E \& Bracken-Grissom, H.D. (2019) A phylogenomic framework, evolutionary timeline, and genomic resources for comparative studies of decapod crustaceans. Proceedings of the Royal Society, B 286, 20190079. https://doi.org/10.1101/466540

Yang, W.T. (1976) Studies on the western Atlantic arrow crab genus Stenorhynchus (Decapod Brachyura, Majidae) I. Larval characters of two species and comparison with other larvae of Inachinae. Crustaceana, 31(2), 157-177. http://dx.doi.org/10.1163/156854076X00198

\section{Captions}


FIGURE 1. Esopus crassus A. Milne-Edwards, 1875, ovigerous female $11.1 \times 6.8 \mathrm{~mm}$, Guadeloupe, KARUBENTHOS 2, E Desirade, st. CP4569, 16²17.25'N, 6059.78'W, 359-250 m, 17 June 2015 (MNHN-IU-2013-18951). Scale: 5 mm. Photograph courtesy of Laure Corbari.

FIGURE 2. Esopus crassus A. Milne-Edwards, 1875, female $11.0 \times 6.7 \mathrm{~mm}$, Guadeloupe, W Marie-Galante, KARUBENTHOS 2, st. DW4586, $15^{\circ} 59.62^{\prime} \mathrm{N}, 61^{\circ} 22.51^{\prime} \mathrm{W}, 251-204 \mathrm{~m}, 21$ June 2015 (MNHN-IU-2013-19002). A, posterior region of carapace, with dotted line delimiting pleurites 5-8 and pleonal somite 1 from carapace; B, rostrum and eye, lateral view (see how the blunt rostrum tapers ventrally by forming a kind of narrow beak that will intercalate between the antennules, as a proepistome); $\mathrm{C}$, anterior region of carapace. a1, first female pleonal somite integrated into carapace; $\mathbf{a} 2-\mathbf{a 3}$, second and third female pleonal somites, dorsally exposed; e, eye retractile in postorbital cup; p.c., postorbital cup; pl5-8, exposed pleurites 5-8 forming kind of collar all around carapace lateral margin; r, rostrum; s.g., setting gutter. Scale: $5 \mathrm{~mm}$ (A-C). Photograph courtesy of MNHN/Poupin.

FIGURE 3. Esopus crassus A. Milne-Edwards, 1875, same data as Fig. 2. A, anterior region of carapace; $\mathrm{B}$, enlarged female pleon, with pleotelson, covering brood cavity; $\mathrm{C}$, pleon lowered. an, antennule; A1, first (urinary) antennal article; A2+3, basal antennal article; e, eye retractile in postorbital cup; ep, epistome; es, epistomial spiniform process; $\mathbf{f}$, antennal flagellum; p, pleotelson; p.c., postorbital cup; pr, rostrum acting as proepistome; $\mathbf{v}$, displaced vulva; 1-3, sternites 1-3. Scales: 3 mm (A-C). Photograph courtesy of MNHN/Poupin.

FIGURE 4. Esopus crassus A. Milne-Edwards, 1875 , male $10.8 \times 6.9 \mathrm{~mm}$, Guadeloupe, $\mathrm{S}$ Marie-Galante, KARUBENTHOS 2, st. CP4624, 1557'N, 61³2’'W, 242-243 m, 26 June 2015 (MNHN-IU-2019-2552). A, ventral surface; B, thoracic sternum, with opened pleon and G1s spaced apart; see sutures inside depressions of sterno-pleonal cavity; C, G1. M.o., MilneEdwards opening, filled by mxp3 coxa; s.pl., sternal extension joining exposed pleurites between pereiopods; s.pt., sternum/pterygostome junction; 1-3, sternites 1-3. Scales: $3 \mathrm{~mm}$ (A, B), $1 \mathrm{~mm}(\mathrm{C})$. Photograph made by Ferran Palero. 
